Article

\title{
Transforming Culture on an Insula Portunalis: Port Cities as Central Places in Early Roman Cyprus
}

\author{
Jody Michael Gordon
}

Department of Humanities and Social Sciences, Wentworth Institute of Technology, Boston, MA 02115, USA; gordonj7@wit.edu

Received: 15 November 2018; Accepted: 6 December 2018; Published: 9 December 2018

\begin{abstract}
During the Early Roman period in the Mediterranean (ca. 30 BC-330 AD), the key central places that distinguished socio-political landscapes were towns. These urban centers functioned as economic and administrative focal points that were controlled by local elites who oversaw wealth redistribution and maintained a dialectical relationship with Rome that mutually benefitted both parties. Yet, beyond providing such rudimentary observations, central place theory has recently been revised to examine how local factors, such as a place's long-term geography and history, intersect with globalizing ones to transform settlement hierarchies as well as economic, political, and cultural landscapes. This article's goal is to explore such intersections through a study of how port towns functioned as central places that connected globalized imperial networks to localized provincial ones within island contexts. It examines a range of material culture including, ceramics, architecture, prestige goods, and coinage from ports in Early Roman Cyprus in order to investigate how the island's integration into Roman networks created central places that altered existing settlement types, hierarchies, and thus, local identities. Overall, this study shows how the reanalysis of central places within their unique geohistorical contexts can shed new light on both regional and state-level processes of cultural change.
\end{abstract}

Keywords: Cyprus; Roman archaeology; Roman imperialism; island and coastal archaeology; identity; urbanism; central place theory; connectivity; maritime cultural landscapes

\section{Introduction}

Cyprum itidem insulam procul a continenti discretam et portuosam, inter municipia crebra urbes duae faciunt claram, Salamis et Paphus, altera Iovis delubris, altera Veneris templo insignis. Tanta autem tamque multiplici fertilitate abundat rerum omnium eadem Cyprus, ut nullius externi indigens adminiculi, indigenis viribus, a fundamento ipso carinae ad supremos usque carbasos, aedificet onerariam navem, omnibusque armamentis instructam, mari committat.

Cyprus, too, an island far removed from the mainland, and abounding in harbours, besides having numerous towns, is made famous by two cities, Salamis and Paphos, the one celebrated for its shrines of Jupiter, the other for its temple of Venus. This Cyprus is so fertile and abounds in products of every kind, that without the need of any help from without, by its native resources alone it builds cargo ships from the very keel to the topmast sails, and equipping them completely entrusts them to the deep. [1] (p. 73)

This passage by the Roman era historian, Ammianus Marcellinus, represents one of the most commonly cited descriptions of ancient Cyprus found within historical and archaeological literature [2] (p. 139), [3] (p. 242). Its ubiquity is not surprising since the passage provides an epigrammatic encapsulation of the island's political, economic, and religious landscapes that offers an effective mise-en-scène for the discussion of historical topics. Ammianus informs us that we are dealing 
with a sea-girt island that is "portuosa," or rich in harbors (Figure 1). He tells us that it "abounds in products" (abundat rerum omnium), which, besides those associated with its fertility (e.g., wine, olive oil, and grain), must include the timber and copper needed to build the cargo ships (oneraria naves) that ply the surrounding sea. We are further told that Cyprus is "crowded" (crebra) with towns (municipia), and that there are two cities (urbes), Salamis and Paphos, with celebrated shrines to the Greco-Roman gods, Zeus-Jupiter, and Aphrodite-Venus. In sum, the passage suggests that Roman Cyprus was economically prosperous because of its export products [2], that it was culturally unique based on its famous cults, and that it was thickly settled with two outstanding urbes-Salamis and Paphos-dominating a hierarchy of municipia. Moreover, Ammianus' characterization of the island as an "insula portuosa" creates a coastal or maritime cognitive geography in which ports, via their links to the oneraria naves and the sea lanes they ply, form network nodes that straddle land and sea, and provide quasi-panoptic gateways to the wider Mediterranean world.

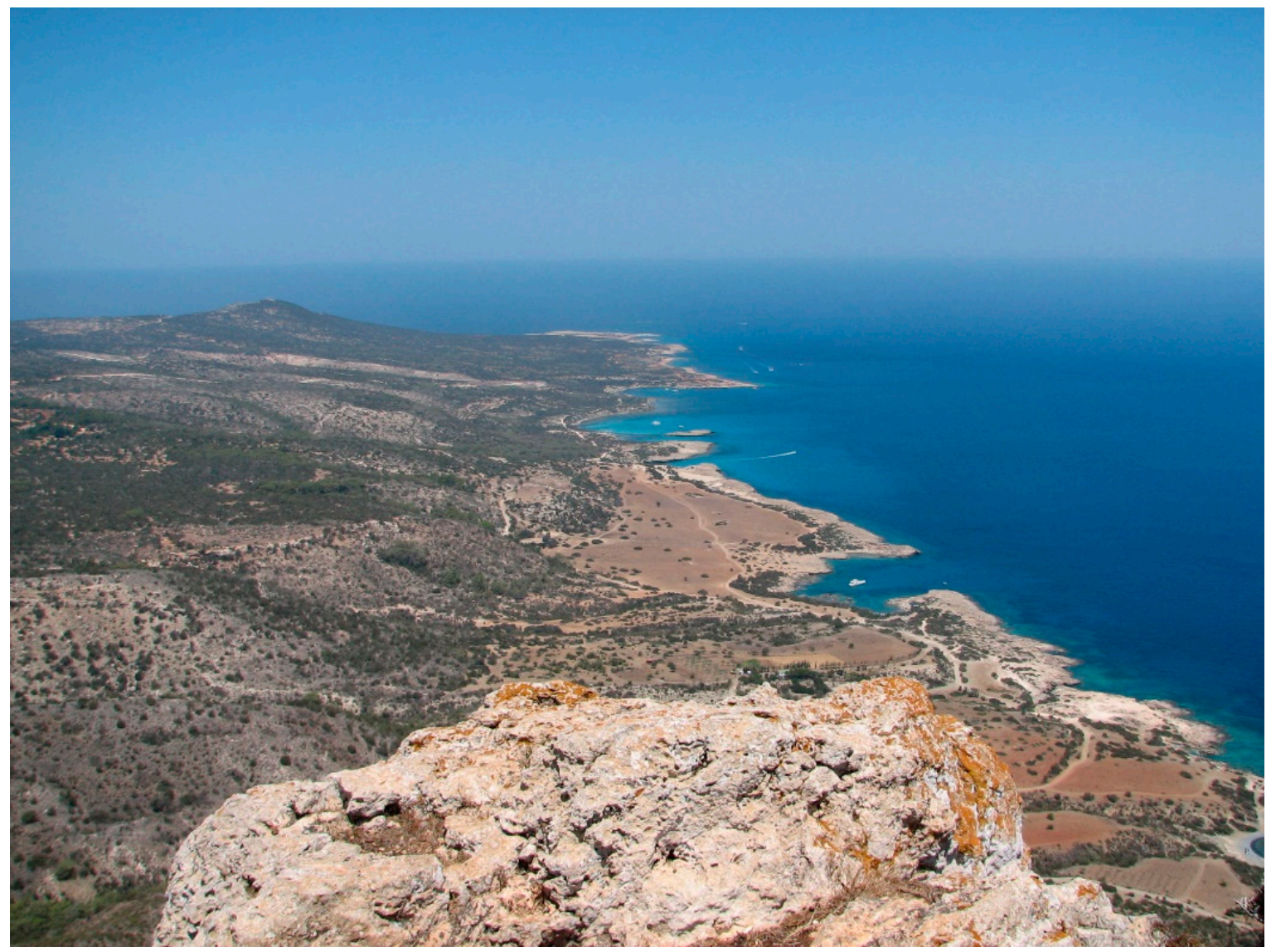

Figure 1. An "insula portuosa." Inlets and bays along the coast of Cyprus looking towards Cape Akamas, the island's farthest northwestern point. Photo by J.M. Gordon.

Although Ammianus' text should be historically contextualized within the mid-fourth century AD, at a time when Salamis, now renamed Constantia, was the island's capital city, and the Roman empire was ruled from Constantinople [4], the archaeological and literary evidence for Cyprus during the Early Roman period seems to paint a similar picture. From ca. 30 BC-300 AD, when Nea Paphos was its capital and Rome was the caput mundi, Cyprus seems to have been an economically self-sufficient and politically stable province [2,5]. The Early Roman archaeological and literary evidence appears largely congruent with Ammianus' observations: ships plied the coastal waters, prestigious imported products (e.g., marble statues) could be acquired at ports, Nea Paphos and Salamis were the largest coastal centers and controlled the island's main cults, and, according to writers like Strabo, Pliny the Elder, and Galen, a wide range of natural resources were marshalled for export [2,6]. The archaeological 
remains from throughout the island also suggest that a new range of social identities were negotiated that were different than those of the preceding Hellenistic era [7]. As mentioned, prestige items like imported wine amphorae [8] and marble statues [9] have been found in the port cities, while in other parts of the island, those areas far away from busy sea lanes or distant from ports, traditional practices continued or settlement contracted [10] (p. 50), [11] (pp. 60-61). Cyprus' integration into the political and economic networks of the Roman empire thus had a significant impact on local reorientations of culture and societal development [12].

Another factor that shaped the transformation of Cypriot society during Early Roman times was the island's unique longue durée (or long-term) geographical and historical features. The analytical value of such features to historical inquiry is important to recognize, and their modern examination can be traced back to the pioneering approaches of the French Annales school, which are best represented in the works of Lucien Febvre [13] and especially, Fernand Braudel [14]. Braudel believed that the analysis of a specific region's long-term history could reveal certain "permanent values," which, although often difficult to discern within analyses of short-term events, could often play a significant role in shaping historical developments. His method involved making "full use of evidence, images, and landscapes dating from other periods, earlier and later and even from the present day," so that the "resulting picture is one in which all the evidence combines across time and space, to give us a history in slow motion from which permanent values can be detected" [14] (p. 23). Hence, if one extrapolates on Braudel's theory, a region's permanent values might include its geographical location, topography, and natural resources, as well as other more "historical" forms of cultural evidence, such as the long-term persistence of certain languages or religious practices—social relics that can be "fossilized" through material remains.

A study of cultural change in Cyprus, an island with evidence for at least 10,000 years of human habitation, should therefore involve not only the analysis of the short-term events that led to changes in economic or political power relations, but also an examination of how the island's long-term geographical, as well as cultural, features shaped society [15]. Yet, what is the broader analytical value of examining cultural change in Roman Cyprus from a Braudelian perspective? As could be argued with regard to its large and centrally-located sister provinces of Crete, Sicily, or Sardinia [5] (pp. 1295-1296), the long-term analysis of cultural change in Cyprus is particularly valuable (and especially from a Roman provincial studies perspective) because it sheds light on how people cultivate unique identities on islands (or notions of "insularity") that are different from those negotiated in continental settings [12]. Therefore, the fact that in antiquity, Cyprus was an island "far removed from the continent, and abounding in harbours" matters in terms of how we interpret its past and the cultural and social identities that its inhabitants negotiated with the wider world.

I have suggested elsewhere [12] that it was this permanent value, Cyprus' insularity, that made the island a culturally unique Roman province, one that could be at once connected, and isolated, from the rest of the Roman Mediterranean depending on the how its geographical and cultural features were negotiated by local, imperial, or even transient, social actors. In this article, I aim to further explore the influence of Cyprus' insularity on local culture by zeroing-in on those places where unique insular features arguably intersected with the social and economic currents of a wider imperial word, that is, Cyprus' port towns. Because complex and multi-directional interactions between islanders and non-islanders and local and imperial agents often occur within the liminal spaces of port cities [16] (pp. 51-52), such an approach also reveals how ports functioned as central places that fostered novel economic and cultural exchanges and catalyzed the transformation of Cyprus' broader social landscapes.

My goal then is to provide an archaeological case study of Early Roman Cyprus' port cities that sheds light on their function as central places within local, regional, and imperial networks, and how their positions within such multi-scalar webs of interaction led to both the disruption of traditional modes of insular life and the creation of uniquely Cypriot social identities. First, I consider the utility of central place theory within the wider context of contemporary archaeological discourse and for 
understanding cultural change in Roman Cyprus. Second, I discuss how I conceive of maritime ports as unique types of central places, especially in island contexts, that facilitated political administration, stimulated economic growth, and permitted a wide range of cross and inter-cultural interactions, including the negotiation of new modes of self-representation. I also suggest that archaeologies of maritime cultural landscapes must be united with terrestrial archaeologies so as to offer a more rounded perspective on island life. Finally, I offer an archaeological case study of how social and economic practices were transformed within Cypriot ports during the Early Roman period. Through the examination of the geographical settings, as well as maritime and terrestrial remains from two first-rank ports, Salamis and Nea Paphos, I show how Rome's conquest of Cyprus integrated these central places into new multi-scalar economic and cultural networks that transformed settlement hierarchies and the ways Cypriot agents identified themselves.

\section{Central Places in the Roman World}

"A place where people interact, a focal point and terminal for commerce and trade involving problems also of geography, geology, history, and economics."

(Anna Marguerite McCann on ports) [17] (p. 11).

In his pioneering work, Central Places in Southern Germany, Walter Christaller developed the study of settlement geography, or Siedlungsgeographie, in order to address the socio-economic processes that affect settlement size, number, and distribution within a given spatial landscape [18] (p. 3). Key to this pursuit was a focus on central places, which have been succinctly defined by Martínez and Tejerizo as "primarily a settlement at the center of a region in which certain types of products and services are available to consumers" [19] (p. 82). The importance, or centrality, of these central places was further defined by Christaller as "the relative importance of place with regard to the region surrounding it, or the degree to which the town exercises central functions," [18] (p. 18) which include the presence of central goods and services (those that are offered or manufactured at a central place) as well as the professions that produce them. These goods and services are distributed to or accessed by the people who exist in a central place's complementary region [18] (pp. 21-22), which is the surrounding landscape of settlements that supports the central place or accesses its services in relation to economic distances based on diminishing returns (e.g., in relation to the time and cost associated with moving products from the regional site to the central place) [20] (p. 113). At this point, since we are dealing with an imperial state in this article, we might also add that a central place often attracts administrative functions and attendant places for ideological or religious practices [19] (pp. 84-85). Such elements might also serve as social magnets for people within a complementary region.

Because Christaller's central place theory is specifically concerned with how settlements come to be and how they influence each other within specific landscapes, it has also proven to have archaeological utility in terms of understanding the function of ancient settlements based on their material remains [19] (pp. 85-86), [21] (p. 212). Such applications of central place theory have been utilized by processualist survey archaeologists in particular [22] (p. 7), who have statistically examined remains from survey regions in order to organize and rank the sites or places of special interest indicated by surface finds and features. These studies have provided an important contribution to scholars' understanding of archaeological landscapes, especially in historical eras with high rates of economic activity and evident urbanism, such as the High Roman empire [23] (pp. 6-8). Yet, over the last twenty years, central place studies have been influenced by new epistemological stresses that reflect our own increasingly globalized world, such as: political and economic complexity and uncertainty, heightened connectivity, regional variability, and the role of human agency in negotiating these factors [24] (pp. 1-2). Perhaps the most notable exploration of these themes has been in Horden and Purcell's The Corrupting Sea, which has stressed the importance of micro-regional connectivity and economic dynamism within the context of the kaleidoscopic, geo-historical Mediterranean longue-durée [25]. As a result, archaeologists have moved beyond the positivist discussion of sherd 
counts or static and cellular notions of economic interaction and have begun to examine the diverse ways that humans could establish central places and experience them [24,26] (pp. 5-9).

During the Roman period, the key central places were arguably towns. In their recent study of Late Antique Spain, Martínez and Tejerizo state that "towns can be seen as the main type of central places within their territory, dotted with villas, mansiones, and other minor rural entities that served as secondary nuclei, and formed the economic and political network from which imperial power was established and maintained" [19] (p. 83). The reason that Roman towns can be viewed from this sociological perspective is because of the types of archaeological evidence they leave behind, such as: a dense surface spread of material remains indicative of large populations, evidence of urban planning and transport infrastructure, evidence for trading connections over a range of distances, the presence of significant public and private buildings and monuments, and often, the presence of industrial or commercial establishments [19] (pp. 85-86). However, if the prototypical Roman urbs can be seen as key to the development of society in continental landscapes, can we utilize it in the same way to understand social change within a maritime or insular environment like Cyprus? I would argue that we can with certain qualifications that reflect the unique features of coastal settlements within a strongly interconnected pre-modern Mediterranean.

\section{Ports as Central Places within Maritime Cultural Landscapes}

The largest towns on the island of Cyprus during the Roman period were Nea Paphos [27] on the island's west coast, and Salamis on the east [28,29] (Figure 2). These urbes (as well as most of Cyprus' smaller municipia) mentioned in Ammianus Marcellinus' famous passage cited above both share one key characteristic: they were located on the island's coasts and served as ports [3] (pp. 227-229). When this observation is combined with the massive expansion of the ancient economy through seaborne trade and market exchange that occurred during the High Roman empire [30] (p. 39), it seems clear that an island city's situation on a coast, especially if it invested in harbor facilities, could play a strategic role in transforming it into a central place where people could congregate for economic, political, and social purposes. Such forces were originally recognized by Christaller [18] (p. 16), who described harbors as "point-bound" central places whose location at the meeting of land and sea routes enhanced their centralizing power, an interpretation that continues to resonate today within island urbanization studies tempered by 21st century globalization theory. For example, Grydehøj et al. [31] (p. 5) suggest that:

One might imagine that globalisation would decrease the significance of the island cities on which these remote communities depend, but it has in fact reinforced the centrality of the old island cities: The more complex and resource-heavy the transport technology, the more important the island city's hub and gateway functions relative to its periphery.

Such a view might also be applied to large Roman coastal cities with significant harbor installations, such as the Cypriot ports of Nea Paphos and Salamis. In fact, this comparison seems even more apt if one views the concept of globalization from a non-presentist perspective and posits, as several scholars currently do [32], that the early Roman imperial period represents a historically unique era of heightened connectivity. Although most of Cyprus' principle ports had existed in pre-Roman times [33] (pp. 30, 37), the archaeological evidence for the expansion of maritime trade at port sites suggests that the island's integration into the "globalized" Roman Mediterranean enhanced ports' regional centrality and made them into the crucibles for multi-scalar, cross-network interactions [3,34]. 


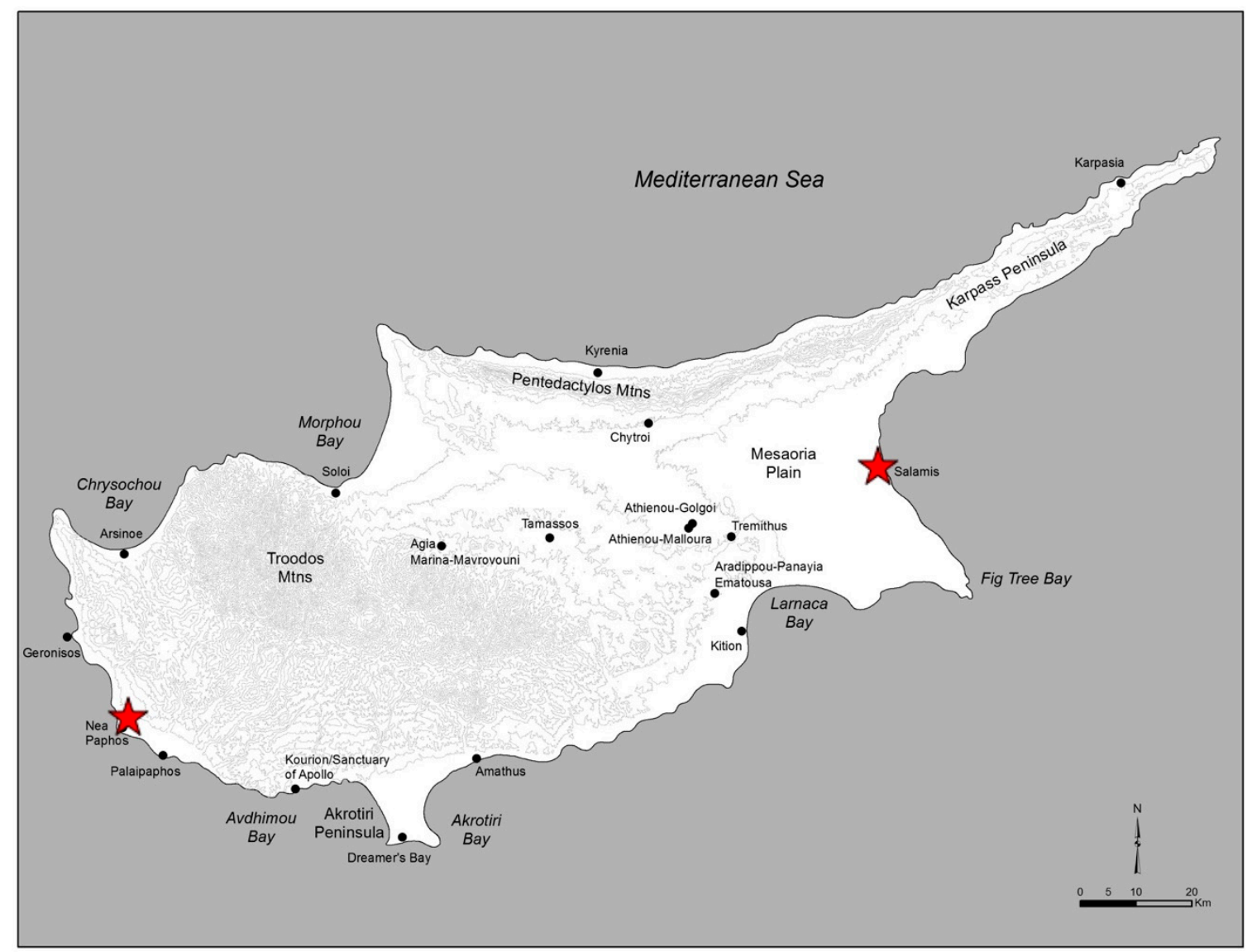

Figure 2. Map of Cyprus showing significant Early Roman period sites. Note Nea Paphos on the west coast and Salamis on the east coast (marked by red stars). Map courtesy of Brandon Olson.

Yet such ports' centrality also marks them out as places that could be fundamentally different to inland island towns, which were located at a distance from the coast and were thus more disconnected from the greater maritime or "global" world. Such coastal/inland social and cultural differences might have been especially marked during pre-modern eras that lacked the telecommunications and transportation technologies we now take for granted, such as in Cyprus during the 19th century when mules were the primary vehicles for inter-city travelers [35]. However, even today, despite our technology, it is likely that most people who engage in an anabasis from a Mediterranean island harbor to a hinterland town will notice how the landscape and altitude, and with it, the perspective of its inhabitants, changes as one heads towards what seems, somewhat paradoxically, an internal frontier-a central region from which there is nowhere to go but back to the coast. In modern Cyprus, one might still experience this phenomenon traveling from the port of Larnaca to the farming villages of the Malloura Valley (an agriculturally fertile region situated in the island's Mesaoria plain; Figure 3), or traveling from the port of Limassol to the alpine villages of the central Troodos mountains. Fernand Braudel also noticed what he called "the historical poverty at the heart of all islands" in the mountains of Cyprus where "there stretched one of the most characteristic no-man's-lands of the Mediterranean, the refuge of the poor, bandits, and outlaws" [14] (p. 154). Hence, one phenomenon of the island port city might be that the more integrated into external networks it becomes, the more its connections to the hinterland and its way of life are altered. Given the lack of archaeological evidence for large-scale urban centers in the Cypriot hinterland during Roman times, it seems that port cities did take on a central role vis-à-vis their complementary regions and that such changes in settlement hierarchy led to different socio-cultural experiences. 


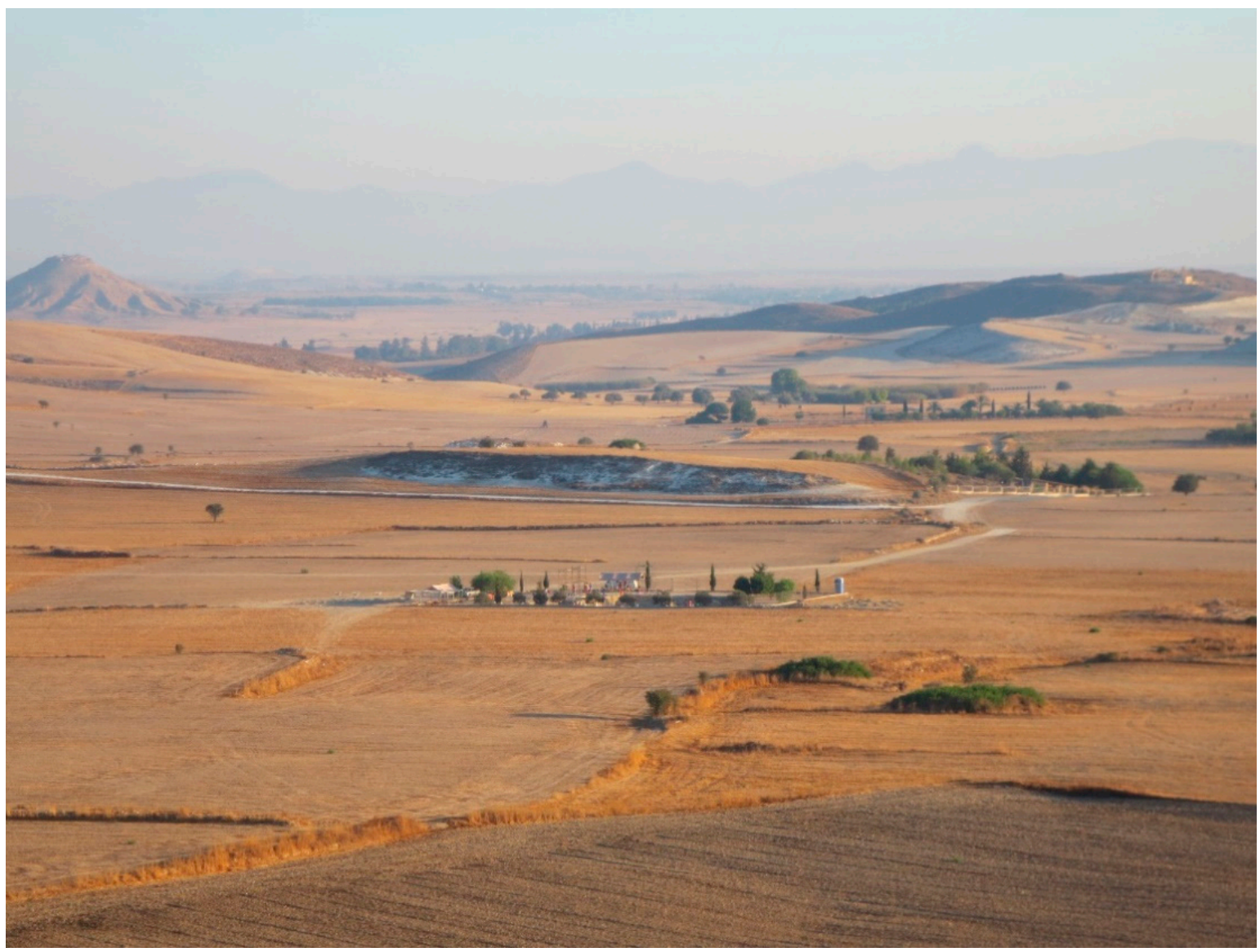

Figure 3. View of the Cypriot hinterland. The valley of Malloura and its ancient sanctuary (center) in the Mesaoria region of Cyprus looking north to the Kyrenia mountain range. Photo by J.M. Gordon.

What kinds of features made ports unique central places in comparison to, say, hinterland market towns [14] (p. 145)? Gary Reger [36] has highlighted four structural features that are characteristic of large maritime ports, whether in antiquity or today: (1) they provide a locus for mixing diverse human agents, (2) they provide a liminal space that connects land and sea, (3) they provide economic-and I would add administrative-institutions, and (4) they are often networked hubs of connectivity in that the they link people to places that are often far removed from the port itself. In his study, Reger focuses on Havana, Cuba in the 16th century as a bustling port with all of these features; however, it is easy to imagine many Mediterranean ports of call fitting such a typologie des escales, such as Valencia, Palermo, Herakleion, Piraeus, Port Said, or Limassol.

One can gain a sense of the bustling and cosmopolitan activity experienced in such ports through Jules Verne's fictional description of 19th century Suez, Egypt-a gateway to the Mediterranean world—in Around the World in Eighty Days:

Little by little the scene on the quay became more animated; sailors of various nations, merchants, ship-brokers, porters, fellahs, bustled to and fro as if the steamer were immediately expected. The weather was clear, and slightly chilly. The minarets of the town loomed above the houses in the pale rays of the sun. A jetty pier, some two thousand yards along, extended into the roadstead. A number of fishing-smacks and coasting boats, some retaining the fantastic fashion of ancient galleys, were discernible on the Red Sea. [37] (p. 37)

Ports, as "sailor towns" [36] (p. 14), thus exude a bustling and cosmopolitan aura that betrays their mixed populations, their locus as liminal spaces, their economic potentialities, and their connections, especially to external locales. In this imagined Suez, we encounter a liminal zone between the Red Sea and the Mediterranean, and another between the sea and the land as the "jetty pier, some two 
thousand yards along, extended into the roadstead." "Sailors of various nations" bustle about, no doubt mixing their languages, religions, and other traditions, while past and present jostle as some coasting boats retain "the fantastic fashion of ancient galleys." Economic institutions are presided over by merchants and brokers, and we can imagine French or British administrative officials exacting their canal zone taxes. All in all, this is a dynamic image of a liminal crossroads between land and sea. It is one of movement and activity that attracts people and connects them. It is also an image of social interaction that likely has more in common with other ports, such as Paphos or Piraeus, than the closest inland Egyptian town. Moreover, we are confronted with the image of a place that centralizes cultural, economic, and administrative needs into a kaleidoscopic hub whose itinerant inhabitants come together, interact, share their goods and traditions, and then return whence they came or head onwards to the next port of call. It is a place of transition, but also of economic and social possibility.

The point of this digression has been to conjure up the image of the port city as an entrepot that clearly has many of the structural features emphasized in central place theory. Maritime ports have wide ranging connections to complementary economic networks of production and consumption, and so they provide a liminal context for the economic and political interactions that attract people to them and allow them to mix. However, they are not traditional central places in the Christallerian sense since the nautical nature of their connections can distort distance cost equations, and their liminal geographical settings provide them with an extra-centralizing feature: the gateway [38] (pp. 269-270), [39] (pp. 110-112).

The Latin word for port, portus, is clearly linked to the word for gate or entrance, porta, which sheds light on how the ancients perceived these liminal places that mediated between the wide open, and often dangerous, world of the sea, and the somewhat safer and more restricted terrestrial connections that prevailed on land. In addition, as has often been the case with port cities, such as Havana or Boston in the American colonial period, the gateway port frequently connects a provincial region to a national core and serves in that role until the frontier moves on, leaving the once important gateway to become a more typical central place that mainly supports the complementary region [38] (p. 270). Other modern examples of such cities in the non-insular sense might be Winnipeg, Manitoba, or St. Louis, Missouri, both of which served as a "gateways to the west" as settlers sought to populate North America during the 19th century, but which today are merely mid-sized regional cities.

In the Roman Mediterranean, ports' connections to local, regional, and even imperial networks allowed them to serve as multi-directional gateways for large complementary areas that expanded, especially through maritime commerce, until they collided with long-term geographical boundaries (such as currents, dangerous coasts, mountain ranges, or non-economically viable lengthy trade routes), or short-term historical events (such as imperial conquest or increased economic competition). These boundaries and developments had a direct effect on the nature of mixing, liminality, economic and political institutions, and connectivity found in centralized ports that served as stimuli for regional settlement patterns and as crucibles for the negotiation of new social identities. For example, a recent study of the economic fortunes of the "gateway" port city of Narona in Dalmatia illustrates how a Roman port town could rise and decline based on its ability to retain its role as an intermediary between its complementary maritime and terrestrial regions [40].

Luckily, many of these gateway cities, such as Narona, have left abundant archaeological remains that permit us to glimpse the nature of life in a Roman port town. Yet, because ports were often Janus-like and acted as gateways to both land and sea, their archaeological stories must not only be terrestrial. Instead, they must also include archaeologies of the sea, with a particular focus on that liminal zone where ports are uniquely situated: the coast. Maritime evidence is thus critical to the study of port cities as central places since previous archaeological studies (and especially surface surveys) that have used central place theory as an interpretive approach to understanding human geographies have often focused on terrestrial sites situated at the nexus of road systems, such as regional towns. The analysis of ports as central places, however, requires one to consider not only such traditional forms of terrestrial archaeology (e.g., monumental architecture, urban planning and infrastructure, or 
imported ceramics), and landscape features (e.g., elevation, hydrology, or strategic location), but also those material remains and geographical markers that make up the maritime cultural landscape.

The maritime cultural landscape is an analytical concept pioneered in the 1970s by Christer Westdahl who described it as a "cross-disciplinary mode of research" that sought "the obliteration of the archaeological border between sea and land, while recognizing the overriding importance of the position of this border in the past so as to analyze and interpret remains and their meanings" [41] (p. 733). For Westdahl, who was diachronically examining Scandinavian coastal remains, this landscape was made up of "—apart from shipwrecks—harbors and ports, including emergency harbors, anchorages, sea inns or taverns (with stage function), ballast sites, shipyards (or boatbuilding sites), maritime settlements and piers or other such constructions, as well as landing places" [41] (p. 736). The archaeological remains typically found within Westdahl's maritime cultural places thus included those elements of material culture that signify human lifeways situated at the porous border of sea and land. Paul Rainbird has attempted to describe the material remains of such maritime landscapes and the communities that created them in the following terms:

Archaeologists of the sea need to identify maritime-related material culture, which can include such things as harbors/quays (sea and military), fishing gear and communal works (as it generally takes more than one person to operate a boat, etc.)...The boat for example, is a very rare find, but we have to start with the assumption that it existed and most likely in a form not found in landlocked communities. Once the boat is acknowledged, then a whole suite of related items of culture must be assumed for the maintenance and operation of such craft. This material culture and its practical and symbolic uses will constitute a distinctive community. [16] (pp. 59-60)

The archaeology of ports, then, requires a focus on the material remains from the intersection of terrestrial and maritime human activity, while also including a maritime cultural landscape interpretive perspective that concentrates on the liminal geographic spaces that ports specifically inhabit, that is, coasts. Thomas Tartaron has defined such areas as coastscapes in the following terms that are pertinent to the geographical and archaeological spaces inhabited by central place ports:

(1) the linear or convoluted shoreline and the adjacent coastal lowland that may be inhabited and exploited by maritime communities; (2) the connective routes and openings into the interior, which are often dendritic and follow natural paths connecting coast and hinterland (e.g., streams, mountain passes). The landward limit of the coastscape is often defined by ridges or mountains that block views to the interior and impede easy passage; (3) the inshore waters that are used on a daily basis for economic and social purposes; and (4) the visual seascape, the everyday field of view that defines the cognitive horizon in the seaward direction in recognition of a continuous cognitive landscape for which the land-sea interface is no boundary. [42] (188)

Considering the foregoing discussion of the interpretive value accrued from approaching port cities' archaeology as one involving both terrestrial and maritime remains within a uniquely coastal landscape, the following analysis of port cities as central places in Early Roman Cyprus attempts to integrate such a panoptic perspective. In doing so, it considers the archaeological remains of Cyprus' maritime cultural landscape (e.g., shipwrecks, harbor structures, and the ceramic evidence for maritime trade; see also Reference [12] (pp. 20-25)) within the context of each port's unique coastscape to offer a critical insight into how ports could function as pivotal central places during Roman times.

\section{The Ports of Roman Cyprus as Central Places}

"In this Roman sea world—to parody George Orwell—all sites were equal—simply "nodes of density," if you like (cabotage and the conditions of navigation saw to that)—but some sites were more equal than others."

(Geoffrey Rickman on the relative importance of Roman ports) [43] (p. 16). 
The following archaeological analysis of the ports of Roman Cyprus as central places is, necessarily, an archaeology of land and sea that examines terrestrial material culture and the maritime networks that supported its acquisition and creation. It draws on a critical mass of evidence that has emerged only in the last three decades from surface surveys and infrastructure studies, underwater port and shipwreck archaeology, terrestrial excavations, and specialist studies of ceramics, numismatics, sculptures, and architecture in order to explore how ports served as centralizing loci for socio-economic change in an island province [15] (pp. 13-27). Although this analysis could be extended to a range of known port sites of various sizes [3,34], I have decided to concentrate here on those two port cities singled out by Ammianus, Salamis and Nea Paphos, which Demetrios Michaelides has called "the leaders in the development in culture and the arts in Roman Cyprus" [44] (p. 128).

These cities also seem appropriate for analysis because their geography and history made them prime candidates to become Roman administrative centers and the largest coastal sites in Cyprus' settlement hierarchy [45] (p. 244). Indeed, if we apply Rickman's [43] (p. 16) Orwellian parody on the connectivity of Roman ports to Cyprus, Nea Paphos and Salamis were "more equal than others." Moreover, if we compare these ports to Verne's [37] (p. 37) vibrant vision of Suez, that is, as what Reger [36] (p. 14) refers to as a "sailor town," we find that the archaeological evidence begins to present a similar image of liminal space, mixing, economic and political development, and intense connectivity. Therefore, as port cities that were "more equal than others," both Salamis and Nea Paphos embody structural features similar to those outlined by Martínez and Tejerizo as characteristic of central places [19].

Cyprus became a Roman senatorial province during the 20s BC [5] (p. 1295). Following the defeat of the Ptolemies, and the removal of their strategoi (i.e., governors) from the capital city of Nea Paphos, the island seems to have been effectively governed by low-ranking annual Roman proconsuls who were assisted by a skeleton crew of officials [5] (pp. 1298-1308). Yet, aside from these Romans in the capital city, there is no evidence for colonies or a major military presence beyond the proconsul's cohort [5] (p. 1296). With a Hellenized culture that had been intermittently influenced by Near Eastern traditions, such as the aniconic worship of Aphrodite [27] (p. 136), the Cypriots spoke Greek and generally attuned with the cultural and economic rhythms of the eastern Mediterranean. Indeed, Cyprus' perennially lucrative geographical location on the sea routes between the Near East and the Mediterranean world assured that these long-term connections persisted into Roman times (Figure 4). As Ammianus and other ancient writers suggest, the island remained prosperous throughout the Early Roman period, and was known for its exports of wine, olive oil, and grain, as well as copper and timber [2]. The Romans supported such export industries by developing an extensive internal road system [46] on Cyprus that connected its coastal towns, but also provided a route across the island's hinterland, likely to access the metalliferous regions near the Troodos mountains [47] (pp. 328-334) and the agricultural bounty of the east-central Mesaoria plain. However, once the resources were extracted, it would be Cyprus' ports and the Cypriot ships that sailed from them that would facilitate their export [6] (p. 846). It was these ports that would serve as central place gateways between the traditional local lifeways of the hinterland, while permitting a mediated contact with the greater imperial world. 


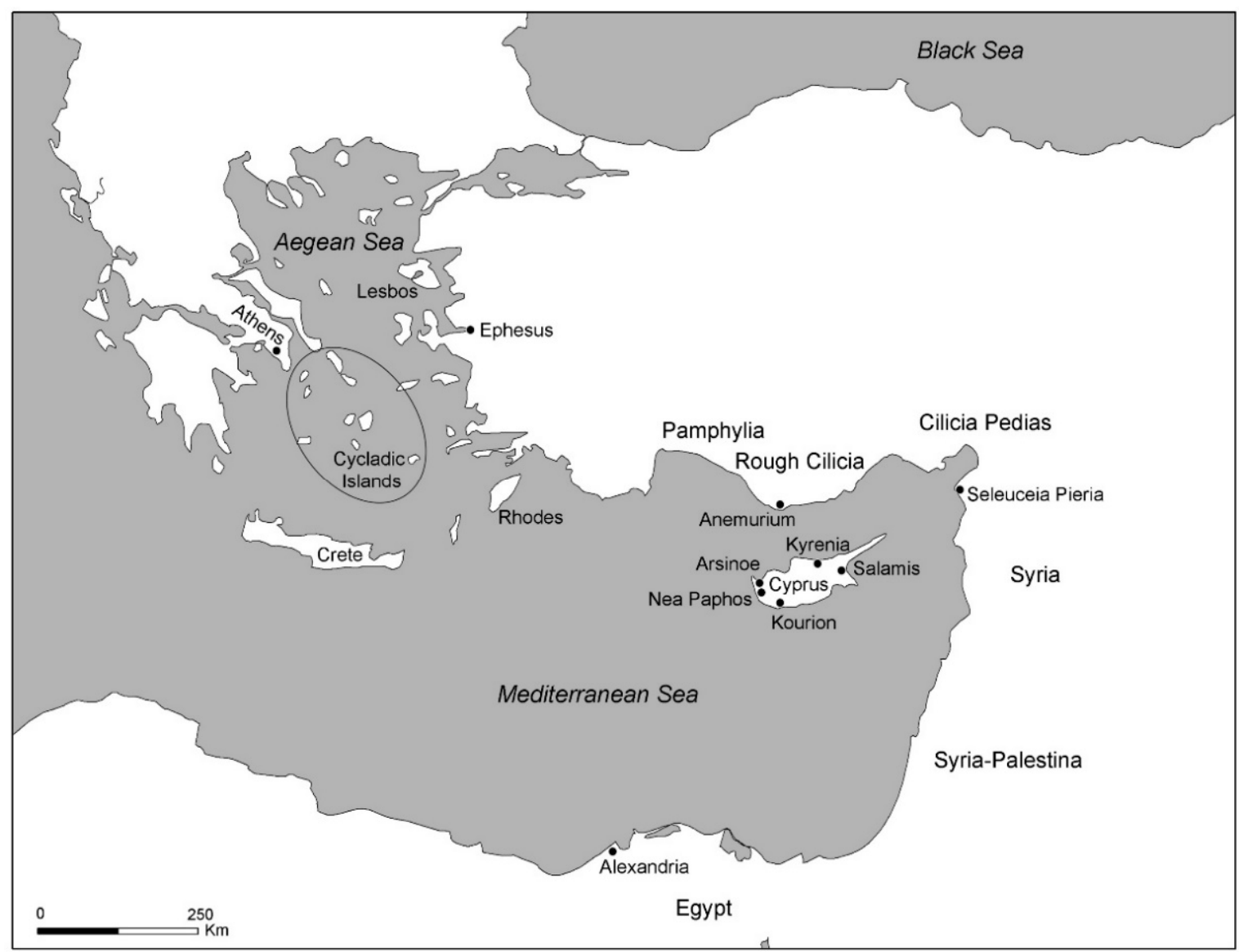

Figure 4. Map showing the location of Cyprus in the maritime world of the eastern Mediterranean during the Early Roman period. Map courtesy of Brandon Olson.

\subsection{Salamis as a Central Place Port}

Salamis' location on Cyprus' eastern coast had been lucrative since the Bronze Age due to the presence of inlets and the Pediaios and Yialias river mouths that connected the coast and sea to the low-lying agricultural heartland of the Mesaoria [33] (p. 30). Hence, the region of Salamis occupied a coastscape that allowed for dendritic terrestrial pathways to extend into the resource-rich interior, while maritime routes could be envisioned, and eventually plied, beyond the seascape's immediate horizon (Figure 5). Although Roman era ships could sail into the wind, sea routes from Salamis towards the mainland, especially to the east and northeast, would have been aided by the prevailing daytime southwesterly winds (especially in the summer and fall) [48] (pp. 38-43), as well as the coastal currents, which flow to the north and east [34] (p. 349). By the Archaic (eighth to sixth centuries BC) and Classical (fifth to fourth centuries BC) periods, Salamis had transformed into one of Cyprus' most prosperous cities and harbors, likely due to its role in exporting copper from the interior [49] (pp. 23-24). Its elaborate built tombs indicate that its Iron Age kings were regionally powerful, and according to historical sources, this power climaxed during the reigns of Evagoras and Nikokreon during the Classical period [50] (pp. 312-317, 332-335). 


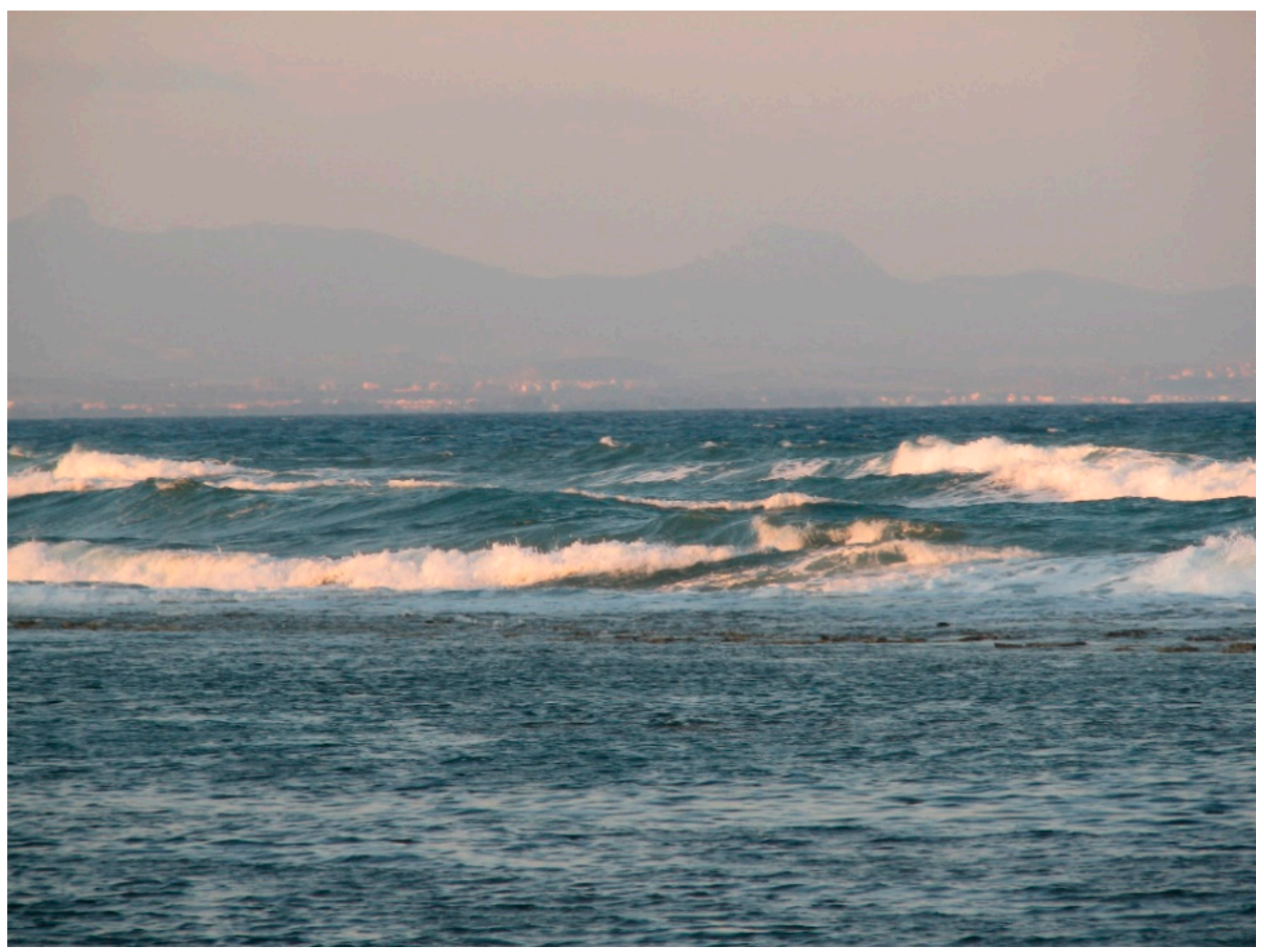

Figure 5. A "sailor's-eye" view of the sea and coastline at the modern Salamis archaeological site looking to the northeast towards the Karpass Peninsula. Photograph by J.M. Gordon.

The city's stature as the most developed port city in eastern Cyprus continued into Hellenistic (late fourth to late first centuries BC) times, when Demetrius Poliorcetes briefly made it into his capital city [49] (p. 167). However, by at least the early second century BC, the new Greco-Egyptian Ptolemaic rulers would transfer the capital to Nea Paphos on Cyprus' west coast, likely because the main harbor facilities at Salamis had silted up [51] (p. 12). This silting seems to have caused either Demetrius or the Ptolemies to transfer the harbor facilities ca. $3 \mathrm{kms}$ north to a site closer to where the major Roman era remains are located today [49] (p. 167). Yet, according to Strabo and the Stadiasmus (an ancient navigational guide likely of the third or fourth centuries AD) [34] (pp. 107-114), another port used by Salamis may have been located about $6 \mathrm{~km}$ to the south at a site known as Arsinoe-Ammochostos, near modern Famagusta [3] (p. 232), [34] (p. 148).

Although little maritime archaeology has taken place at these sites, the ancient sources do mention harbors $(\lambda \iota \mu \varepsilon \varepsilon \varepsilon \varsigma)$ being present. A $\lambda \iota \mu \eta^{\prime} v$ is difficult to define, but it likely utilized natural bays, or in the case of Salamis, offshore reefs, enhanced by breakwaters [52] (p. 813). Based on the evidence from Mediterranean shipwrecks, large harbors would have been unnecessary, even at larger cities, as many ships involved in coastal trade seem to have been well under 100 tons [53] (p. 560), and so a great deal of product unloading could have been done with small skiffs or by simply wading to shore [53] (p. 561), [54] (pp. 33-34). John Leonard [34] (p. 148) has even proposed that ships coming to Roman Salamis might have anchored in the sheltered side of reefs directly opposite from the seafront (Figure 6). 


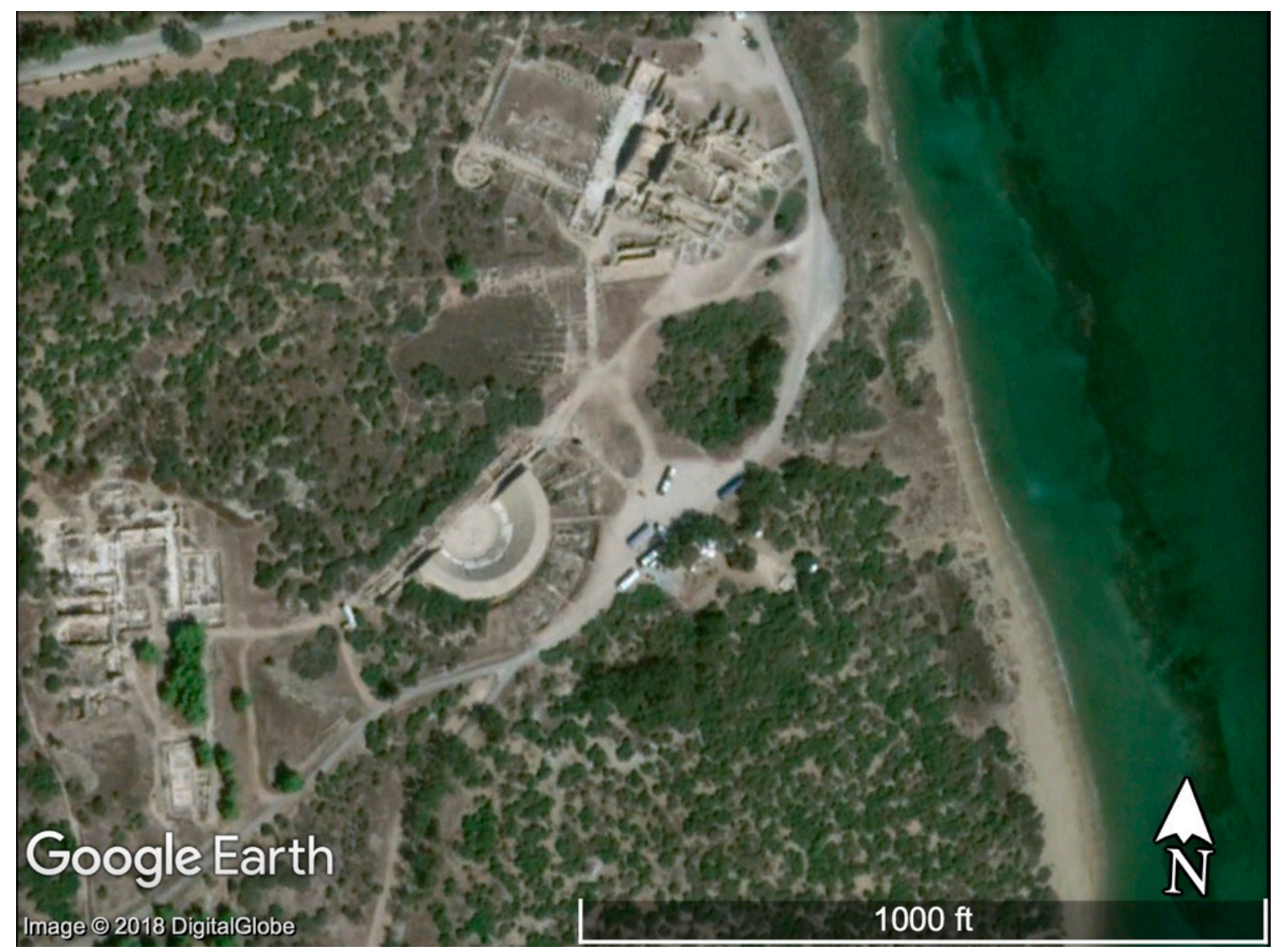

Figure 6. Aerial view of the modern ruins of Roman Salamis showing the location of the theater, gymnasium, and baths. Note the reefs visible in the sea to the east. Source: Google Earth; Map Data: Google, Digital Globe.

According to The Oxford Roman Economy Project's online database of shipwrecks [55], out of the 18 shipwrecks known from Cypriot waters, only 6 may date to some point during the Early Roman period. Based on its find-spot, the only wreck from this group that may shed light on the types of ships that plied the waters near Roman Salamis is one analyzed by Justin Leidwanger from Fig Tree Bay [56], located roughly $20 \mathrm{~km}$ south of the port city. Although the wreck has only been surveyed, and it was not found in Salamis' immediate coastal waters, its proposed second century AD date and 5-6 ton cargo of over 130 amphorae capable of carrying wine, olive oil, or other products does provide some, albeit minimal, evidence for the types of ships that may have visited eastern Cypriot ports during Roman times. Was this one of the onerariae naves constructed in Cypriot shipyards mentioned by Ammianus? It is difficult to say, but the relatively small ship did have an impressive international cargo, which included amphorae not only from Cilicia, but also from as far away as Gaul. Despite the complex trading mechanisms that may have been involved in acquiring such a diverse cargo, Leidwanger [56] (pp. 203-204) suggests that these products may have been picked up via local tramping in small and large ports along the Syrian and Cilician coasts. Thus, although there is little archaeological evidence for Salamis' built harbors [34] (p. 147), and if the Fig Tree Bay wreck can be cited as plausible evidence for Roman era seafaring practices, the port city seems to have offered an adequate location for coastal transactions of products, such as olive oil and wine, from as far away as the western Mediterranean.

In addition to its ability to connect to external maritime trade, Salamis also served as a coastscape gateway to Cyprus' richest agricultural region, the Mesaoria [57] (p. 13). It is clear that the hinterland in the immediate vicinity of Salamis was well populated with a range of settlement types since 63 Roman era sites were discovered by Sophocles Hadjisavvas during a surface survey [58] (p. 249). This region would have been connected to Salamis by a radial series of roads that led to the city, and 
Bekker-Nielsen [46] (p. 110) has identified four in particular: one north to the Karpass Peninsula, one heading south toward Kition, one heading northwest toward Chytroi (to which an aqueduct was also eventually built), and a final one leading towards the Kitian chora near the farming establishment of Panayia Ematousa [11].

Unfortunately, not much is known about how land was held in Roman Cyprus, but David Potter [6] (p. 849) assumed that it was controlled by local urban elites whose estates produced agricultural products, such as wine, olive oil, and grain for maritime export. Such a thesis seems likely since, by the early second century AD, Salamis appears to have grown into a large-scale central place supported by an economic base rooted in agricultural production, perhaps some manufacturing, and trade [34] (pp. 806-810). Salamis' site size was approximately 275 hectares [45] (p. 244), making it double the known size of the capital of Nea Paphos, and it had all of the key structural elements of a thriving port city.

Its economic and administrative functions are in evidence based on epigraphy and archaeology. Salamis' epigraphic record [59] (p. 240) sheds light on the massive wealth and political power that could be accrued by native Cypriots as the region's agricultural goods were prepared for export from the city's massive agora by workers, such as members of the flax-weavers guild [44] (p. 122). For example, extant dedicatory inscriptions illustrate that during the Flavian era (60s-90s AD), the Salaminian and Roman citizen, Sergius Sulpicius Pancles Veranianus, was able to be the high priest of Cyprus three times, the ambassador to the emperor three times, the builder of the theater and bath house, and the donor of imported marble statues to the amphitheater [60] (p. 119). He also no doubt spent time in the city's lavish gymnasium's palaestra, which today sports a striking colonnade made of costly imported marble (Figure 7). John Leonard [34] (p. 810) assumes that Pancles made his fortune, at least partly, via the maritime trade derived from Salamis' central location.

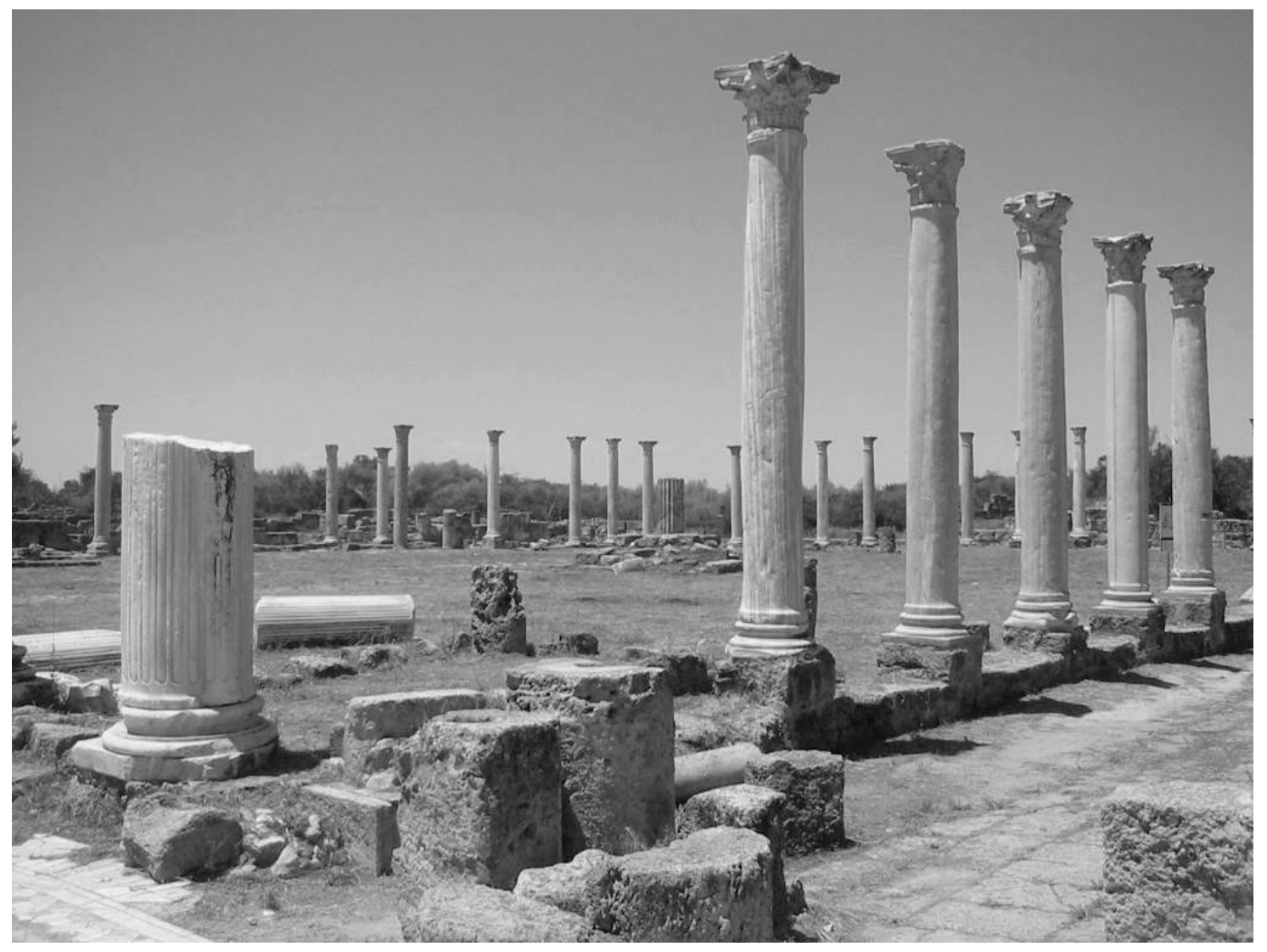

Figure 7. The Salamis gymnasium palaestra showing the imported marble colonnade. Photograph by J.M. Gordon. 
As Salamis' civic benefactions attest, the city was well decorated with the architecture of Romanitas, illustrating a clear connection to other cities in the region, such as Seleucia-in-Pieria, the port of Antioch, and likely the marble-rich cities of western Asia Minor or the Aegean. Salamis' prominence in Cyprus is illustrated on Roman coins of the period [61] (pp. 40-41, 87) (Figure 8), which highlight the importance of the city's primary deity, Zeus Salaminios, while its international fame is attested to in the ancient literary sources, through its rebuilding by Hadrian after a local revolt [57] (p. 143), and through its position as an administrative conventus [44] (p. 116). Such cross-cultural interaction is also evident among the site's imported marble statues, such as the statue of Zeus Capitolinus [62] (pp. 31-32) from the gymnasium's palaestra or the interspersing of imperial cuirassed statues with images of Greek deities (including Apollo, Dionysos, and possibly Aphrodite) in the city's theater [63] (pp. 175-185). Such religious mixing is also evident from biblical and literary sources, which describe St. Barnabas, a native of Salamis, and St. Paul arriving at Salamis by sea from Seleucia-in-Pieria and worshipping in the synagogues of the Jews [64].

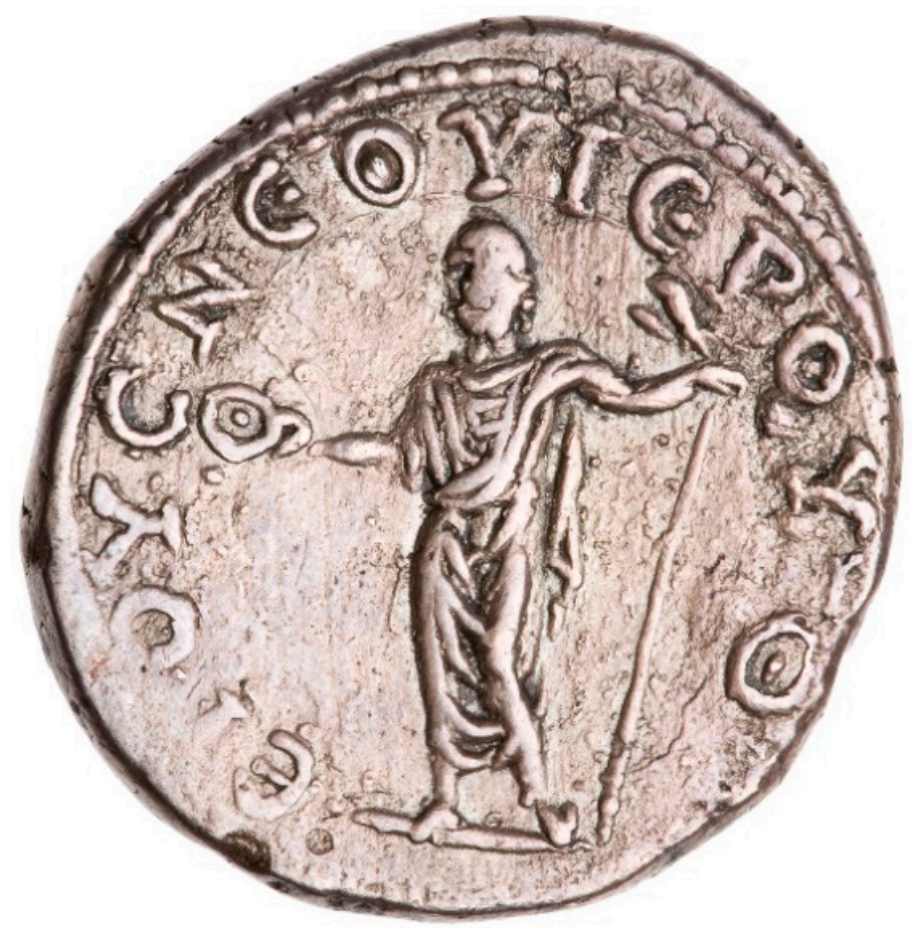

Figure 8. Reverse image of the statue of Zeus Salaminios on a silver tetradrachm minted under the authority of the emperor Vespasian for Cyprus (77-78 AD). Image courtesy of the American Numismatic Society.

Salamis thus seems to have had all of the key structural features of a centralized, port city [45] (p. 243). It was a center of economic and political development that dominated the seemingly small sites of its local hinterland, it was a gateway or liminal zone not only to the Cypriot interior, but also to the greater sea-lanes of the eastern Mediterranean, and its multifaceted connectivity encouraged the mixing of people and ideas from the Salamis region, the eastern Mediterranean, and even from Rome itself when people like Pancles served as "ambassadors to the emperor." In essence, Salamis became a liminal, yet centralizing, focal point whose economic, political, and cultural influence can be detected throughout the Mesaoria [5] (p. 1323). It was the type of place where local culture could become global, and where new social identities that combined the insular and the cosmopolitan could be shaped. Salamis, as a Roman port city, was a crucible for cultural change. 


\subsection{Nea Paphos as a Central Place Port}

Having discussed the most important central place on Cyprus' east coast, it is instructive to compare how the predominant site on the island's west coast, the Roman capital of Nea Paphos, also functioned as not only a regional central place, but perhaps also an economic and administrative gateway for the entire Roman province.

Nea Paphos was founded in the Late Classical period by Nikokles [65] (pp. 67-75), [66] (pp. 287-288), the last king of the Paphian kingdom, which had been previously centered at the site of Palaipaphos (or "Old Paphos"), located about $20 \mathrm{~km}$ east of Nea Paphos and famous for its ancient sanctuary of the Cypriot god par excellence, Aphrodite [27] (pp. 238-251). As was the case with Salamis, the site of Nea Paphos was likely selected due to its strategic location. It presents another economically advantageous coastscape with a relatively low-lying site (which included two hills that served as seafaring landmarks) that also had access to the region's upland forests and copper-bearing areas [65] (p. 18), [66] (p. 287). However, it was likely its promontory position at the nexus of Cyprus' western and southern coasts that transformed it into a "sailor town" since ships coasting the island would have had to round the cape as they sailed to the east or northwest. Moreover, based on the prevailing westerly winds and Cyprus' counter-clockwise currents [34] (p. 349), Nea Paphos could further serve as a starting point for sailors wanting to tramp along Cyprus' southern coasts or even head into open waters destined for or returning from Alexandria in Egypt [34] (pp. 340-341). Indeed, such southern voyages may have increased during the Hellenistic period when the Ptolemaic kingdom transferred Cyprus' administrative capital from Salamis to Nea Paphos [51] (p. 12) and developed the city's protected southern harbor as a site for the construction and outfitting of naval ships [65] (p. 109). When the Romans conquered the island, they also recognized Nea Paphos' strategic location as a gateway city [45] (p. 246), and so the city remained the provincial capital and home of the proconsul [44] (p. 116), [65] (pp. 133-134). Strabo describes its harbor as a $\lambda \iota \mu \eta \dot{v}$ [3] (p. 232), while the Stadiasmus refers to it as triple harbor for all winds, a designation that has been difficult to understand [34] (p. 586).

Archaeological research on Nea Paphos' main southern harbor indicates that it would have had large-scale western and eastern breakwaters. These barriers extended from the Hellenistic city walls and came together to form a small entrance between two fortification towers [67] (pp. 199-201) that could be closed by a chain creating what ancient writers refer to as a $\lambda \iota \mu n \dot{v} \kappa \lambda \varepsilon\llcorner\sigma \tau o ́ s$ (a term which Scylax uses to describe Salamis' harbor, and Strabo utilizes to discuss Kition (modern Larnaca)) [48] (p. 813) (Figure 9). Some of this construction was likely Ptolemaic, but the presence of concreted sections also suggests Roman interventions, likely following the known earthquakes of 15 BC or 77 AD [34] (p. 586). There is no evidence for a triple harbor; however, recent research by the Polish Paphos Agora Project has explored the possibility that some boats may have accessed the city at a point near the northwest city wall [68] (pp. 12-15). Whether this area was the location of a now silted-over harbor feature or not remains unclear, but John Leonard has also noted D.G. Hogarth's suggestion that the sea once extended inland to the city wall gate and that "a descending ramp with steps at the bottom once served as a convenience for boats" [34] (p. 588).

The presence of one large built harbor as well as possible ancillary boat launches at Nea Paphos emphasizes its role as a major maritime administrative and economic hub that served as a gateway for imports to and exports from the Cypriot hinterland. Although no Early Roman shipwrecks have been discovered along Paphos' coasts (the closest ancient shipwrecks of any date are found closer to Kourion to the east or the Akamas Peninsula to the north [55]), judging by the size of the city's main harbor [68] (p. 9), it seems that many different ship sizes could have unloaded at quays on the inner sections of the eastern or western moles [69] (pp. 650-653) with products coming from a range of foreign ports. For example, Anthi Kaldeli's analysis of the imported amphorae discovered at Nea Paphos [70] (p. 130) shows that Cyprus' exchange network with the western Mediterranean mainly involved passing through the capital city of Nea Paphos, since amphorae from Italy, Gaul, Spain, Portugal, and North Africa, have all been found in larger numbers than at other Cypriot sites. 
Clearly, Roman Cyprus' capital was a place where traders from throughout the Mediterranean could economically and socially intermix with both local Cypriots and Roman administrators [5] (p. 1321).

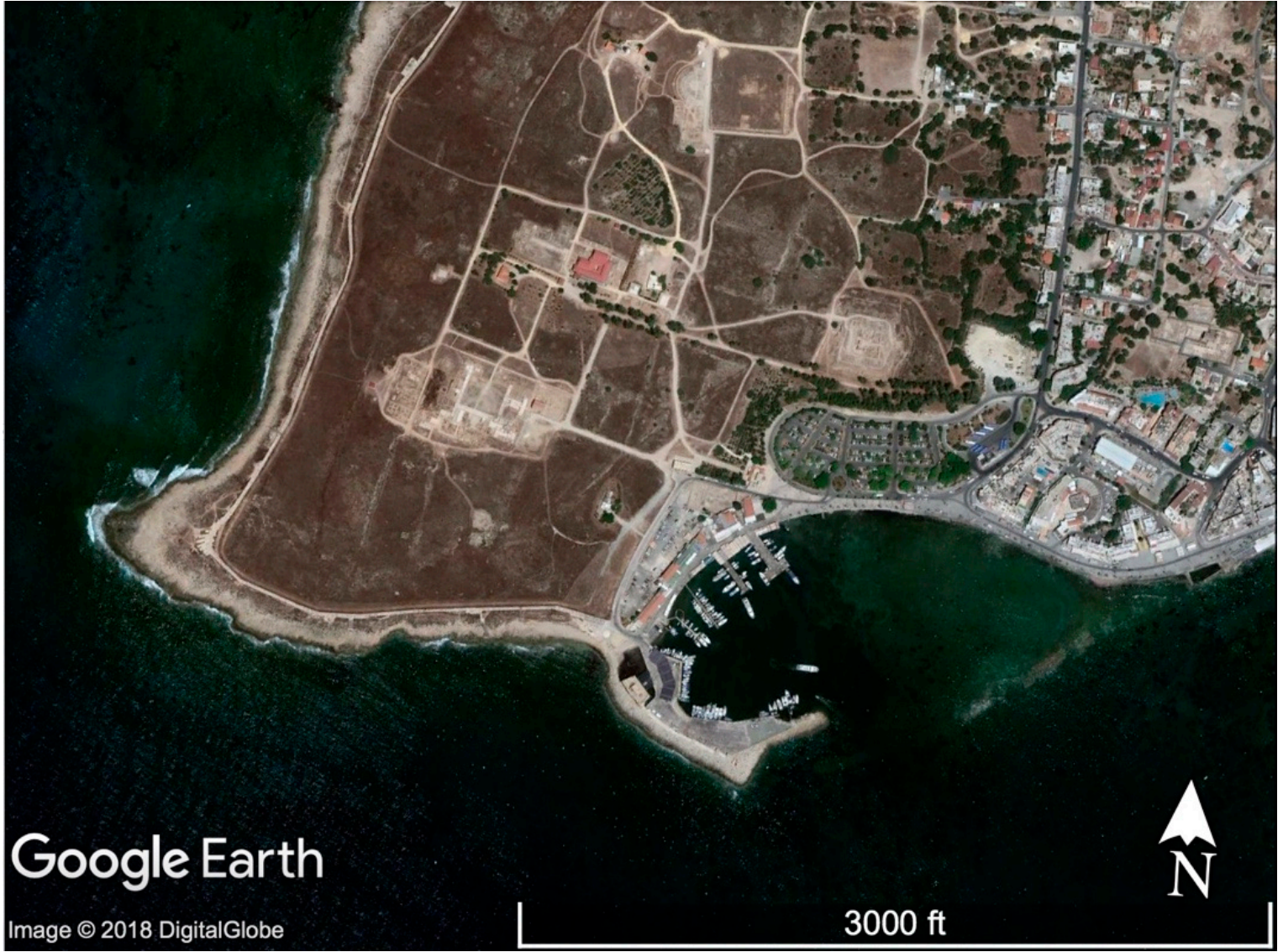

Figure 9. Aerial view of the modern Nea Paphos archaeological site. The remains of the southern port's breakwater are visible at the bottom right. Source: Google Earth; Map Data: Google, Digital Globe.

Nea Paphos' exports, like those from Salamis, likely came from its immediate hinterland. Since it was closer to the Troodos mountains, alpine timber for ships and perhaps copper from the foothills might have been exported via the port city along with local grain [65] (p. 109). The more famous products of wine and olive oil mentioned by Pliny the Elder [2] (p. 139) would likely have been available as well. If Cypriot sigillata fineware or pinched-handle amphorae [71] (pp. 166-168, 172-174) were made in western Cyprus as some scholars believe, then these ceramics may have also been exported from Nea Paphos. The timber, copper, and grain could have been brought to the coast via one of the three roads that Bekker-Nielsen [46] (p. 110) has identified as radiating out of Nea Paphos, one to the north, one to the west, and one to the east, with the eastern road likely serving as Strabo's hieros odos that connected the shrines of Aphrodite in Nea Paphos to her ancient ones in Palaipaphos [5] (pp. 1309-1310). The need to bring export products to market, the presence of wealthy Cypriot middlemen and Roman administrators, and the availability of imported products from ceramics to wine, likely caused many people living in the hinterland to migrate towards this central place to find their fortunes [6] (p. 842).

Such a scenario can be supported by David Rupp's analysis of the Canadian Palaipaphos Survey Project (CPSP) data, which examined the settlement patterns of the Paphian hinterland [45]. Rupp's team revealed an expansion of settlement throughout the Paphos region during the Late Hellenistic and Early Roman period [45] (pp. 252-253). Moreover, based on the idea that Nea Paphos' population likely increased leading to a need for settlements to expand beyond the city's Hellenistic era walls, the CPSP revealed the likely presence of a hierarchy of settlements from tiny farmsteads 
of approximately 1 hectare in size to suburban small towns all situated within about $20 \mathrm{~km}$ from the city center [45] (pp. 247-249). These settlements, judging by the lack of sophisticated architectural finds, were likely inhabited by lower class agricultural workers and small-scale craftsmen whose agricultural surpluses supported the urban elites in the capital. Rupp labeled this type of development a "dendritic" central place system since the second and third rank settlements, typically situated along roads, rivers, or the nearby coastline, acted like roots that nourished the central place [45] (p. 249). A similar relationship between a central place and its region might also be observed at the small southeastern port of Pyla-Koutsopetria, which recent survey evidence suggests was a thriving maritime village in Early Roman times with likely administrative links to the larger port of Kition about $10 \mathrm{~km}$ to the west [72] (p. 289). The dendritic phenomenon that lay behind Cypriot settlement patterns is further espoused by Bekker-Nielsen, who recognized that the roads of Roman Cyprus "formed part of long-distance trading networks, but in a secondary and ancillary role in relation to sea transport" [73] (p. 13). Thus, due to a central place's parasitic economic power, people were likely drawn to live closer to it and its maritime connections. This observation is valuable because it begins to explain why some non-coastal Cypriot archaeological sites, such as Idalion or Tamassos, have not yielded similar globalized trappings (such as imported marble-clad buildings or sculptures) to those found in coastal urban centers [5] (pp. 1331-1332) and why several rural sanctuaries went into decline during Roman times [10] (p. 50).

The archaeological remains from the urban center of Nea Paphos further indicate that the city profited both from its liminality as a portal to its hinterland, and as a maritime gateway to the wider Roman world. Although many urban spaces excavated in the city likely date to the Hellenistic period, including the city's agora and theater [68] (pp. 4-5), Nea Paphos' increased centrality in the Roman era caused these areas to become monumentalized. For example, the agora gained an imported marble colonnade [27] (p. 225) while the theater acquired a baroque scenae frons [74] (pp. 179-183), likely through imperial euergetism. In addition, judging by its appearance on Roman coins (Figure 10), the Sanctuary of Aphrodite at Palaipaphos, complete with its ancient tripartite temple and aniconic baetyl, which was visited by such voyagers as the future emperor Titus [60] (p. 99), was likely enhanced architecturally during the Roman era. This sacred monumentalization was not only enacted so as to reinforce the fame of Cyprus' foremost religious shrine, but it was also aimed at transforming it into a center of imperial cult worship [27] (p. 272), a fact supported by the discovery of the so-called "Oath of Allegiance to Tiberius" at the site [60] (pp. 77-91), an imperial oath sworn by the aristocratic leaders of Cyprus' league of cities: the Koinon Kyprion. The funding for monumentalizing the city and its nearby sanctuary likely came from a combination of local and imperial funds, since literary sources and coins may indicate that Nea Paphos received imperial aid following earthquakes in 15 BC and 77 AD [65] (p. 33), [61] (p. 95). Nea Paphos' administrative primacy in Roman imperial Cyprus is echoed in the city's full epigraphic titulature as well, which by the early third

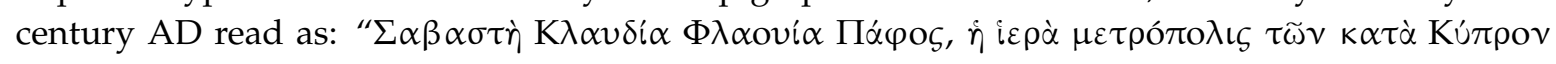
$\pi \hat{\lambda} \lambda \varepsilon \omega v^{\prime \prime}$ (Augusta, Claudia, Flavia Paphos, the holy metropolis of the cities in Cyprus) [5] (p. 1310). Although, one extant inscription competitively shows that Salamis also referred to itself as Cyprus' mother-city [59] (pp. 142-143), the larger volume of inscriptions describing Nea Paphos as "metropolis" seems to solidify its elevated political position [5] (p. 1314).

The cultural effects of Nea Paphos' centrality were perhaps best witnessed in the elaborately decorated villas of Early Roman date that were discovered to the south of the city's agora [27] (pp. 226-235). Excavations have revealed a series of large Roman atrium houses of second and third century AD date, which are decorated with elaborate mosaic floors that indicate cultural dialogues with wider Greco-Roman culture [75] (p. 5). In the so-called "House of Dionysos," depictions of the Greek myths of the Triumph of Dionysos (Figure 11), Piramus and Thisbe, and Ganymede rival mosaics found throughout the Roman east [76], while images of the seasons or hunting seem similar to topics found in North Africa. 


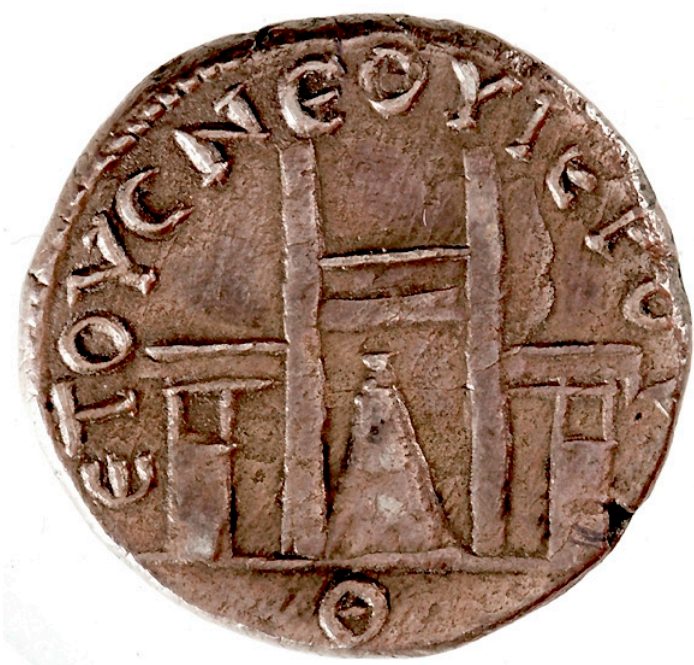

Figure 10. Reverse image of the Temple of Aphrodite at Palaipaphos on a silver tetradrachm minted under the authority of the emperor Vespasian for Cyprus (77-78 AD). Image courtesy of the American Numismatic Society.

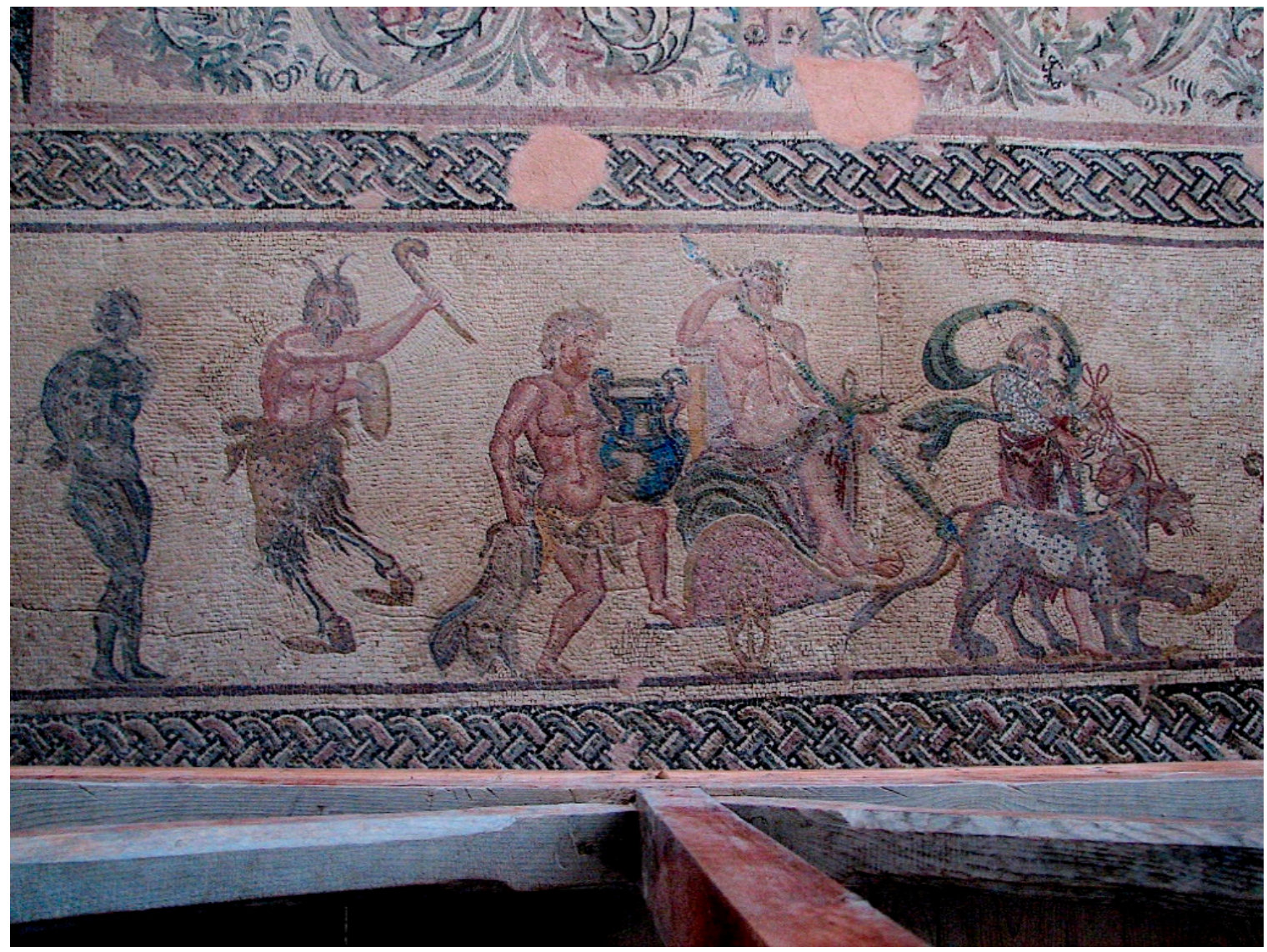

Figure 11. Floor mosaic from the House of Dionysos, Nea Paphos, showing the Triumph of Dionysos. Photo by J.M. Gordon.

Imported marble statuary found in the houses also reflects the choices made by the denizens of Roman Nea Paphos [9] (pp. 111-117). Sections of the Late Roman "House of Theseus" also proved to have been decorated with a range of second century AD imported marble statues and statuettes. Unique statues, such as the Aphrodite Armata (or Hoplismene) [77] (Figure 12), were combined with more traditional Roman copies of Greek originals representing Asclepius, Artemis, and 
Hercules indicating a penchant for works that were meaningful to both local and elite Roman viewers. Taken together, these types of evidence suggest that Nea Paphos' economic and administrative functions, along with its liminality and connectivity, made it an ideal center for the types of cross-cultural mixing that could lead to the negotiation of culture and the creation of new identities. Like Salamis, it served as a centralizing hub, not only for its hinterland and western Cyprus, but also perhaps for ships sailing between Nea Paphos and Alexandria, the embarkation point for the Egyptian ships in Rome's famous annona grain fleet [70] (pp. 131-132), [78] (p. 266).

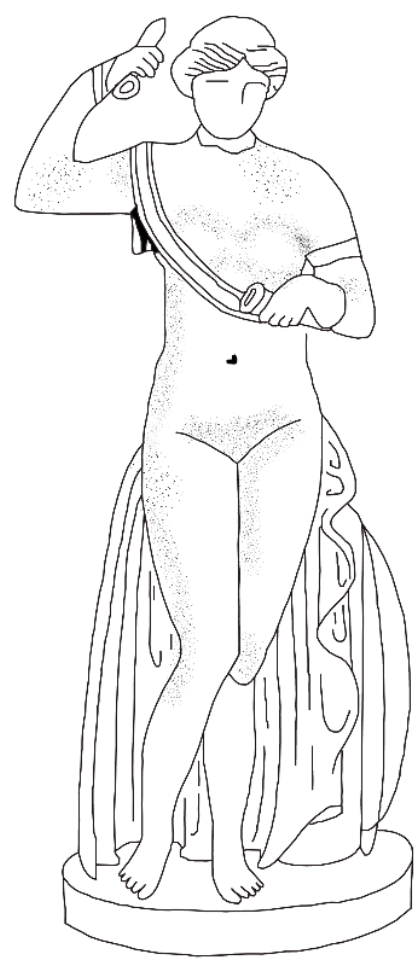

Figure 12. A reconstruction of the Aphrodite Armata statue from the House of Theseus at Nea Paphos. Digital drawing by J.M. Gordon, after Daszewski 1982, p. 199, Figure 1 [77].

\section{Conclusions: Cyprus-Insula Portuosa or Insula Portunalis?}

In sum, I would like to offer a few observations about how the two major port cities of Cyprus, Salamis and Nea Paphos, functioned as central places that fostered the expanded economic development of their regions and served as contexts for the social interactions that transformed local culture during the first three centuries AD. Returning to Reger's [36] structural features that make ports unique central places, both Salamis and Nea Paphos were marked by their liminality and connectivity. According to surface surveys and road network analyses, they both served as coastscape gateways that connected a terrestrial hinterland of smaller settlements to an open-ended range of maritime networks buoyed up by Rome's protection of shipping [72] (p. 289) and the imperial center's need to exploit its provinces [8] (p. 368). That the Romans appreciated Cyprus' ports, and especially Salamis and Nea Paphos, is evidenced through their appointment of an epigraphically attested, Lymnarcha Cypri [44] (p. 116), and because imperial funds were likely used to repair both cities following earthquakes and social disturbances. The evidence gleaned from each city's maritime cultural landscape, which includes shipwreck, amphora, and harbor remains, as well as the presence of favorable winds and currents, further indicates that both direct long-distance and indirect short-haul trade could be experienced. In addition, the evidence suggests that both sites had harbor facilities capable of accommodating various sizes of ship, from relatively small crafts, like the Fig Tree Bay ship, to perhaps larger "oneraria naves," such as the vessels of the annona grain fleet. 
This connectivity, along with the longue durée, "permanent value" factors of coastscape location and religious importance, allowed for Salamis and Nea Paphos to continue their Hellenistic era prominence and emerge as large-scale economic and administrative centers during the Early Roman era. Both ports offer evidence for the economic success of their elite landholding classes and also reveal local elites' collaboration with the imperial Roman authorities in efforts to centralize administrative power [8] (p. 376). Indeed, as Martínez and Tejerizo [19] (p. 85) have pointed out, most central places require such elites as mediators between the socio-economic needs of their complementary regions and those of wider states: "Central places can be analyzed as a reflection of elite power in a particular region, and, at the same time, as the consequence of a dialectic and dynamic balance between state and regional elites." Hence, in some ways, the central place cities of Roman Cyprus, with their elite leaders like Sergius Sulpicius Pancles Veranianus, were evidently not so different in function to those of Late Antique Spain [19] or even Aztec Mexico [20] (p. 116).

Yet, even if Nea Paphos became the provincial capital, why was Salamis able to rise to a rivaling level of regional centrality? How could a relatively small, insular landscape like Cyprus support two first-rank, central place ports with different long-term permanent values during Roman times? We can infer that this situation likely resulted from several factors, which allowed each port to cultivate and manipulate its own sphere of terrestrial and/or maritime influence.

First, these two ports were separated by a large terrestrial boundary in Cyprus' mountainous interior, the Troodos Massif and its surrounding foothills, which may have set a physical limit on the dendritic power of each port's economic control of the hinterland. However, despite such geographical barriers, it still seems that each port had access to a significant complementary resource zone, with Salamis controlling the larger and more fertile terrestrial areas of the Mesaoria. Nea Paphos, on the other hand, in order to compensate for its lesser terrestrial sphere, may have prospered by virtue of its strategic coastal location on the island's southwest promontory, which granted it access to profitable maritime networks.

Because Cyprus' two largest port cities were in different geographical locations vis-à-vis west to east trade routes, winds, and currents, the ships that arrived at their harbors seem to have had different cargoes, at least judging by the available archaeological evidence [56,70]. This fact reveals that each port was involved in differing networks of connections, and hence, was open to diverse economic and political possibilities. Thus, even if Salamis' hinterland might have provided more access to Cyprus' agricultural and metallic resource potential, perhaps Nea Paphos' connections to more lucrative sea networks, including those possibly plied by the imperial annona fleet, presented the western port's citizens with greater access to the expanded economic possibilities accrued from trans-Mediterranean trade. Such connections to sea routes favored by traders, soldiers, or functionaries who represented Roman imperial interests may have also solidified Nea Paphos' role as provincial administrative capital. This political status likely increased the port's nature as a regional central place from which the Roman proconsul adjudicated the laws and kept the peace, as St. Paul's famous meeting with Sergius Paullus indicates [64].

The differing maritime connections of Nea Paphos and Salamis have also been emphasized by John Lund in his long-term analyses of ceramic circulation trends in Cyprus: "Western Cyprus was connected with Rough Cilicia, whereas Eastern Cyprus and the Easternmost part of Southern Cyprus were similarly tied to Smooth Cilicia and North-eastern Syria" [71] (p. 242). Moreover, Anthi Kaldeli, in her study of mechanisms of exchange in Roman Cyprus, showed that Nea Paphos was the main gateway for goods coming from the west to the island, while sites like Amathus-and likely Salamis as well-were "primarily involved in eastern exchange networks" [70] (p. 130), perhaps similar to those evidenced by the Fig Tree Bay shipwreck's cargo [56]. Hence, in Christallerian terms, it would seem that each central place's maritime and terrestrial complementary region provided unique cultural and economic benefits that, when combined with each city's permanent geographic and cultural values, resulted in both ports experiencing an enhanced level of regional centrality within the histoire événementielle of the Pax Romana. 
These port cities' liminality, connections, and economic/political development made them into ideal central loci for the mixing of people from the Cypriot hinterland, other regional ports, or even from as far away as Egypt, Rome, or Spain. It was in the dynamic coastscapes of these cities-their harbors, agoras, theatres, and gymnasia-that new notions of what it meant to be Cypriot in the Roman world were negotiated. Therefore, it is here that we see Cypriots building baths and amphitheaters and decorating them with mosaics and marble statues similar to those found in other port cities throughout the Roman world. Yet, since Cyprus' ports likely also hosted practices found in prototypical "sailor towns," like socio-cultural mixing, we also see some local choices in terms of material evidence for the veneration of local deities, like Zeus, and especially Aphrodite, that were long connected to Cypriot myth-history. In fact, it was these two deities who were chosen to represent Cyprus' two central place ports on the Cypriot coinage, with the Temple of Aphrodite at Palaipaphos (Figure 10) featured on some reverses, and the Statue of Zeus Salaminios (Figure 8) featured on others [5] (p. 1322). These central places also seem to have utilized different calendars [60] (pp. 144-156), with Nea Paphos, as the administrative capital, adopting an imperial calendar, while Salamis retained an older, Egyptian calendar [5] (p. 1314). It is difficult to say whether the use of different calendars indicates competition between the cities, but it does show that civic identities in Roman Cyprus, especially in large central places, were meaningful on the regional level [59] (p. 254).

It is also interesting to note that these central places' wealth did not seem to "trickle down" to the hinterland sites that supported their rise. Although imported ceramics have been found at some interior sites, like the farming settlement at Panayia Ematousa [79] (pp. 205-217) or the necropolis at Athienou-Magara Tepeşi [80] (Figure 13), most places assumed to be small farming villages or resource extraction centers lack the evidence for monumentality or conspicuous consumption. This state of affairs was also witnessed in the mining regions of the Troodos mountains where the Troodos Archaeological and Environmental Survey Project (or TAESP) team found that "no evidence for consumer wealth or elite settlements could be associated with this period, suggesting that the wealth from the rich natural resources was not redistributed locally" [47] (p. 333). The central place ports were economically parasitic.

Even the smaller harbors that made Cyprus into an "insula portuosa" do not seem to rival those of Salamis and Nea Paphos. Instead, these second-rank ports, such as Dreamer's Bay, which Stella Demesticha and John Leonard have identified as a "busy maritime emporium" (with approximately $0.5 \mathrm{~km}$ of archaeological surface features currently being explored by the University of Leicester [81] (p. 10)) where "imports intended either for local consumption or further exchange via cabotage" [82] (pp. 201-202) were unloaded, nonetheless never attained the centripetal economic and cultural force required to sustain a first-order central place. Further evidence for such "cabotage" ports has also been found at Pyla-Koutsopetria near Kition. Here, surface survey has revealed that table ware pottery, like Eastern Sigillata A, likely from Syria, was more common than Cypriot Sigillata (from either western Cyprus or Cilicia), even as the main Early Roman forms of imported wine and olive oil amphorae arrived from western sources in the Aegean [72] (p. 290). Although it is not impossible that these wares arrived at Pyla directly from their sources, the nature of the assemblage hints at more complex, and less centralized, trading mechanisms (such as those gleaned from the Fig Tree Bay ship's cargo [56]), with imported products being unloaded at larger ports like Kition and Salamis and then being distributed via different, likely short-haul, regional modes (either by land or sea) to smaller sites [72] (p. 291), [54] (pp. 33-34). Thus, Cyprus' central place ports seem to have created several nodal orders in terms of social identities during Roman times. The first order ports fostered wealthy cosmopolitan identities that was forged by the economic and political possibilities of highly connected central places. Conversely, in the second and third order sites located in the deep hinterland or along infrastructurally intermittent coastal bays and beaches, people's identities were conditioned by each site's relative connectedness to the economic opportunities offered by maritime networks during the Early Roman period. 


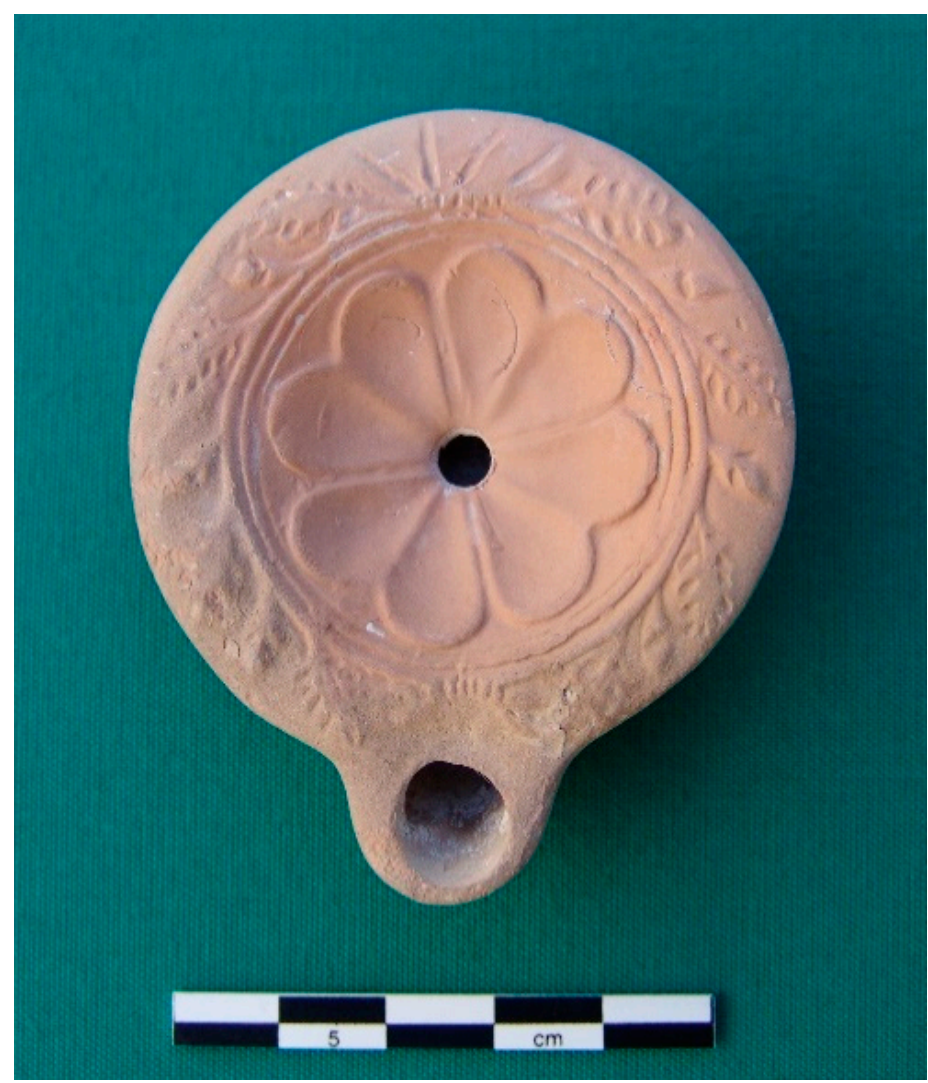

Figure 13. A Roman mold made lamp recovered from a rock-cut chamber tomb at Athienou-Magara Tepeşi. The lamp was likely made by the "Romanesis" workshop on Knidos in the Aegean Sea and imported to Cyprus during the early second century AD. Photo courtesy of the Athienou Archaeological Project.

Given Cyprus' long and accessible coastline, Ammianus Marcellinus was wise to refer to it as an "insula portuosa." However, taking into account the foregoing analysis of Cyprus' central place ports, Salamis and Nea Paphos, a more appropriate term may have been an "insula Portunalis" or a "Portunus-like" island where "some sites were more equal than others." The Roman god Portunus, whose name is related to "porta" or "gate," was not only the god of ports as gateways to the sea [83] (p. 516), but he was also closely related to Janus, the Roman god of boundaries, crossing places, or passages who is typically depicted with two conjoined heads looking in opposite directions [84] (p. 587). Hence, Cyprus, like Janus, seems to have been endowed with two heads in the form of Salamis in the east and Nea Paphos in the west, two central places that each dominated their surrounding territories until such connections were interrupted or manipulated by either a longue durée geographic feature (e.g., the Troodos mountains) or a short-term structural force (e.g., a competing port, such as Seleucia-in-Pieria or Rhodes, or perhaps the intervention of Roman imperial policy, such as the possible route of the annona ships). Overall, the Roman period in Cyprus may mark a turning point when Cyprus' largest port cities transformed the insula "portuosa" into an insula "Portunalis," a change that would have significant repercussions for the island's settlement hierarchy, landscapes, and ultimately, the identities of Cypriots as active participants in the connected and increasingly globalized world of the Roman Mediterranean.

Funding: This research received no external funding.

Acknowledgments: I would like to thank the editors of this special issue of Land, Giorgos Papantoniou and Athanasios Vionis, for inviting me to take part in the initial conference session on central place theory at the 2018 International Congress of Classical Archaeology in Bonn, Germany and for their patience in the receipt of this manuscript. In addition, I want to thank the anonymous peer reviewers who provided insightful commentary 
on this article and who urged me to emphasize the importance of maritime archaeology to the study of ports as central, coastal places. Thanks are also due to the American Numismatic Society (and especially, Elena Stolyarik), Brandon Olson, and the Athienou Archaeological Project for their permissions to reproduce images. I would further like to thank the editors at Land for publishing this special volume, which I feel represents an important contribution to the reexamination of the role of central places in the ancient Mediterranean world. Lastly, I would like to thank my wife, LeeAnn Gordon, for her support and encouragement while I worked on this article.

Conflicts of Interest: The author declares no conflict of interest.

\section{References}

1. Rolfe, J.C. Ammianus Marcellinus Volume 1; Loeb Classical Library: Cambridge, MA, USA, 1950; ISBN 0-674-99331-4.

2. Michaelides, D. The Economy of Cyprus during the Hellenistic and Roman periods. In Development of the Cypriot Economy: From the Prehistoric Period to the Present Day; Karageorghis, V., Michaelides, D., Eds.; Lithographica: Nicosia, Cyprus, 1996; pp. 139-152, ISBN 9789963607105.

3. Leonard, J. Evidence for Roman Ports, Harbours and Anchorages in Cyprus. In International Symposium Cyprus and the Sea; Karageorghis, V., Michaelides, D., Eds.; University of Cyprus: Nicosia, Cyprus, 1995; pp. 211-227, ISBN 9789963607082.

4. Gordon, J.M.; Caraher, W.R. The Holy Island: An Archaeology of Early Christian Cyprus. In Oxford Handbook of Early Christian Archaeology; Pettegrew, D.K., Caraher, W.R., Davis, T.W., Eds.; Oxford University Press: Oxford, UK, 2018; pp. 473-494, ISBN 9780199369041.

5. Mitford, T.B. Roman Cyprus. In Aufstief und Niedergang der Römischen Welt 27.2; De Gruyter: Berlin, Germany, 1972; pp. 1285-1384, ISBN 9783110018851.

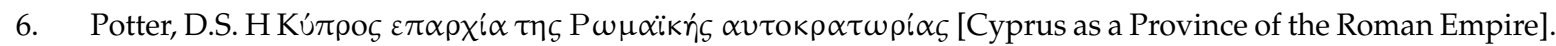

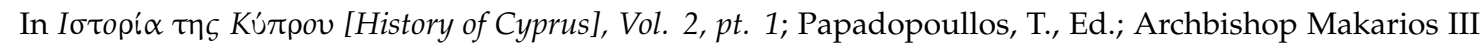
Foundation: Nicosia, Cyprus, 2000; pp. 763-864, ISBN 9963556426. (In Greek)

7. Gordon, J.M. To Obey by Land and Sea: Empires, the Mediterranean, and Cultural Identity in Hellenistic and Roman Cyprus. In Across the Corrupting Sea: Post-Braudelian Approaches to the Ancient Mediterranean; Concannon, C., Mazurek, L., Eds.; Routledge: London, UK, 2016; pp. 133-164, ISBN 9781472458261.

8. Kaldeli, A. Trade and the Transmission of Roman Values to Cyprus, as Evidenced by the Amphorae. Cah. Centre d'Études Chypr. 2009, 39, 365-386. [CrossRef]

9. Fejfer, J. Sculpture in Roman Cyprus. In Panayia Ematousa: A Rural Site in South-Eastern Cyprus II; Wriedt Sørensen, L., Winther Jacobson, K., Eds.; Monographs of the Danish Institute at Athens 6.2; Danish Institute at Athens: Athens, Greece, 2006; pp. 81-123, ISBN 9788772888361.

10. Papantoniou, G. Cyprus from Basileis to Strategos: A Sacred-Landscape Approach. Am. J. Arch. 2013, 117, 33-57. [CrossRef]

11. Sørensen, L.W. Introduction: Stratigraphy and summary of the site analysis. In Panayia Ematousa: A Rural Site in South-Eastern Cyprus I; Sørensen, L.W., Winther Jacobsen, K., Eds.; Monographs of the Danish Institute at Athens Volume 6.1; Danish Institute at Athens: Athens, Greece, 2006; pp. 34-63, ISBN 9788772888361.

12. Gordon, J.M. Insularity and Identity in Roman Cyprus: Connectivity, Complexity, and Cultural Change. In Insularity and Identity in the Roman Mediterranean; Kouremenos, A., Ed.; Oxbow Books: Oxford, UK, 2018; pp. 4-40, ISBN 9781785705809.

13. Febvre, L. A Geographical Introduction to History; Mountford, E.G.; Paxton, J.H., Translators; Routledge: London, UK, 1924.

14. Braudel, F. The Mediterranean and the Mediterranean World in the Age of Philip II; Reynolds, S., Translator; Harper \& Row: New York, NY, USA, 1972; ISBN 9780060104528.

15. Gordon, J.M. Between Alexandria and Rome: A Postcolonial Archaeology of Cultural Identity in Hellenistic and Roman Cyprus. Ph.D. Discussion, University of Cincinnati, Cincinnati, OH, USA, 2012.

16. Rainbird, P. The Archaeology of Islands; Cambridge University Press: Cambridge, UK, 2007; ISBN 9780521619615.

17. McCann, A.M. Introduction: A Perspective. In Roman Port and Fishery of Cosa: A Center of Ancient Trade; McCann, A.M., Bourgeois, J., Gazda, E., Oleson, J.P., Will, E.L., Eds.; Princeton University Press: Princeton, NJ, USA, 1987; pp. 3-11, ISBN 9780691035819. 
18. Christaller, W. Central Places in Southern Germany; Baskin, C., Translator; Prentice Hall: Englewood Cliffs, NJ, USA, 1966.

19. Martínez, J.; Tejerizo, C. Central Places in the Post-Roman Mediterranean: Regional Models for the Iberian Peninsula. J. Med. Arch. 2015, 28, 81-103. [CrossRef]

20. Smith, M.E. The Aztec Marketing System and Settlement Pattern in the Valley of Mexico: A Central Place Analysis. Am. Antiq. 1979, 44, 110-125. [CrossRef]

21. Bintliff, J.L. Going to Market in Antiquity. In $\mathrm{Zu}$ Wasser und zu Land: Verkehrswege in der Antiken Welt; Olshausen, E., Sonnabend, H., Eds.; Geographica Historica 17; Franz Steiner Verlag: Stuttgart, Germany, 2002; pp. 209-250, ISBN 9783515080538.

22. Athanassopoulos, E.F.; Wandsnider, L. Mediterranean Landscape Archaeology Past and Present. In Mediterranean Archaeological Landscapes: Current Issues; Athanassopoulos, E.F., Wandsnider, L., Eds.; University of Pennsylvania Press: Philadelphia, PA, USA, 2004; pp. 1-13, ISBN 9781931707732.

23. Alcock, S.E. Graecia Capta: The Landscapes of Roman Greece; Cambridge University Press: Cambridge, UK, 1993; ISBN 9780521568197.

24. Papantoniou, G.; Vionis, A.K. Landscape Archaeology and Sacred Space in the Eastern Mediterranean: A Glimpse from Cyprus. Land 2017, 6, 40. [CrossRef]

25. Horden, P.; Purcell, N. The Corrupting Sea: A Study of Mediterranean History; Blackwell: Malden, MA, USA, 2000; ISBN 978063121906.

26. Caraher, W.; Moore, R.S.; Pettegrew, D.K. Introduction. In Pyla-Koutsopetria I: Archaeological Survey of an Ancient Coastal Town; Caraher, W., Moore, R.S., Pettegrew, D.K., Eds.; American Schools of Oriental Research Archaeological Reports 21; The American Schools of Oriental Research: Boston, MA, USA, 2014; pp. 1-16, ISBN 9780897570695.

27. Maier, F.-G.; Karageorghis, V. Paphos: History and Archaeology; A.G. Leventis Foundation: Nicosia, Cyprus, 1984; ISBN 9789963560011.

28. Karageorghis, V. Excavating at Salamis in Cyprus, 1952-1974; A.G. Leventis Foundation: Athens, Greece, 1999; ISBN 9789607254764.

29. Yon, M. La ville de Salamine: Fouilles Françaises 1964-1974/The Town of Salamis: French Excavations 1964-1974. In Kinyras: L'Archéologie française à Chypre; Yon, M., Ed.; Travaux de la Maison de l'Orient et de la Méditeranée 22; De Boccard: Paris, France, 1993; pp. 139-158, ISBN 9782903264512.

30. Wilson, A. Developments in Mediterranean shipping and maritime trade from the Hellenistic period to AD 1000. In Maritime Archaeology and Ancient Trade in the Mediterranean; Robinson, D., Wilson, A., Eds.; Oxford Centre for Maritime Archaeology 6; Institute of Archaeology, University of Oxford: Oxford, UK, 2011; pp. 33-60, ISBN 9781905905171.

31. Grydehøj, A.; Barceló Pinya, X.; Cooke, G.; Doratl, N.; Elewa, A.; Kelman, I.; Pugh, J.; Schick, L.; Swaminathan, R. Returning from the Horizon: Introducing Urban Island Studies. Urban Island Stud. 2015, 1, 1-19. [CrossRef]

32. Pitts, M.; Versluys, M.J. (Eds.) Globalisation and the Roman World: World History, Connectivity and Material Culture; Cambridge University Press: Cambridge, UK, 2014; ISBN 9781107619005.

33. Iacovou, M. Historically Elusive and Internally Fragile Island Polities: The Intricacies of Cyprus's Political Geography in the Iron Age. Bull. Am. Soc. Orient. Res. 2013, 370, 15-47. [CrossRef]

34. Leonard, J. Roman Cyprus: Harbors, Hinterlands, and 'Hidden Powers. Ph.D. Discussion, State University of New York at Buffalo, Buffalo, NY, USA, 2005.

35. Counts, D.B.; Parvis, J.A. Mapping Malloura: A Carto-Historical Survey from the Early Modern to the Present. In Crossroads and Boundaries: The Archaeology of Past and Present in the Malloura Valley, Cyprus; Toumazou, M.K., Kardulias, P.N., Counts, D.B., Eds.; Annual of the American Schools of Oriental Research 65; American Schools of Oriental Research: Boston, MA, USA, 2012; pp. 55-65, ISBN 9780897570862.

36. Reger, G. Nodes of Sea and Sand: Ports, Human Geography, and Networks of Trade. In Ancient Ports: The Geography of Connections. Proceedings of an International Conference at the Department of Archaeology and Ancient History, Uppsala University, 23-25 September 2010; Höghammer, K., Alroth, B., Lindhagen, A., Eds.; Boreas: Uppsala Studies in Ancient Mediterranean and Near Eastern Civilizations 34; Uppsala Universitet: Uppsala, Sweden, 2016; pp. 9-36, ISBN 9789155496098.

37. Verne, J. Around the World in Eighty Days; Towle Geo, M., Translator; James, R., Ed.; Osgood and Company: Boston, MA, USA, 1873. 
38. Burghardt, A.F. A Hypothesis about Gateway Cities. Ann. Assoc. Am. Geogr. 1971, 61, 269-285. [CrossRef]

39. Bird, J.H. Of Central Places, Cities and Seaports. Geography 1973, 58, 105-118.

40. Lindhagen, A. Narona in Dalmatia-The rise and fall of a "gateway settlement". In Ancient Ports: The Geography of Connections. Proceedings of an International Conference at the Department of Archaeology and Ancient History, Uppsala University, 23-25 September 2010; Höghammer, K., Alroth, B., Lindhagen, A., Eds.; Boreas: Uppsala Studies in Ancient Mediterranean and Near Eastern Civilizations 34; Uppsala Universitet: Uppsala, Sweden, 2016; pp. 225-251, ISBN 9789155496098.

41. Westdahl, C. The Maritime Cultural Landscape. In Oxford Handbook of Maritime Archaeology; Katsambis, A., Ford, B., Hamilton, D.L., Eds.; Oxford University Press: Oxford, UK, 2011; pp. 733-762, ISBN 9780195375176.

42. Tartaron, T.F. Maritime Networks in the Mycenaean World; Cambridge University Press: Cambridge, UK, 2013.

43. Rickman, G. Ports, Ships, and Power in the Roman World. In Maritime World of Ancient Rome: Proceedings of "The Maritime World of Ancient Rome" Conference held at the American Academy in Rome 27-29 March 2003; Hohlfelder, R., Ed.; Memoirs of the American Academy in Rome, Supplementary Volumes; University of Michigan Press: Ann Arbor, MI, USA, 2008; Volume 6, pp. 5-20, ISBN 9780472115815.

44. Michaelides, D. The Roman Period. In Footprints in Cyprus, Revised ed.; Hunt, D., Ed.; Trigraph: London, UK, 1990; pp. 110-135, ISBN 0950802603.

45. Rupp, D. 'Metro' Nea Paphos: Suburban Sprawl in Southwestern Cyprus in the Hellenistic and Earlier Roman Periods. In Urbanism in Antiquity: From Mesopotamia to Crete; Aufrecht, W.E., Mirau, N.A., Gauley, S.W., Eds.; Journal for the Study of the Old Testament. Suppl. Ser. 244; Sheffield Academic Press: Sheffield, UK, 1997; pp. 236-262, ISBN 9781850756668.

46. Bekker-Nielsen, T. The Roads of Ancient Cyprus; Tusculanum Press, University of Copenhagen: Copenhagen, Denmark, 2004; ISBN 9788772899565.

47. Winther-Jacobsen, K. Hellenistic and Roman Landscapes. In Landscape and Interaction: The Troodos Archaeological and Environmental Survey Project, Cyprus. Volume 1: Methodology, Analysis and Interpretation; Given, M., Knapp, A.B., Noller, J., Sollars, L., Kassianidou, V., Eds.; Oxbow Books: Oxford, UK, 2013; ISBN 9781782971870.

48. Murray, W.M. Ancient Sailing Winds in the Eastern Mediterranean: The Case for Cyprus. In International Symposium Cyprus and the Sea; Karageorghis, V., Michaelides, D., Eds.; University of Cyprus: Nicosia, Cyprus, 1995; pp. 33-44, ISBN 9789963607082.

49. Karageorghis, V. Salamis: Recent Discoveries in Cyprus; New Aspects of Archaeology; McGraw-Hill: New York, NY, USA, 1969.

50. Maier, F.-G. Cyprus and Phoenicia; The Cambridge Ancient History: Cambridge, UK, 1994; pp. 297-336, ISBN 9781139054379.

51. Nicolaou, I. Prosopography of Ptolemaic Cyprus; SIMA 44; Paul Åströms Förlag: Göteborg, Sweden, 1976; ISBN 9789185058709.

52. Oleson, J.P.; Hohlfelder, R.L. Ancient Mediterranean Harbors in the Mediterranean. In Oxford Handbook of Maritime Archaeology; Katsambis, A., Ford, B., Hamilton, D.L., Eds.; Oxford University Press: Oxford, UK, 2011; pp. 809-833, ISBN 9780195375176.

53. Houston, G. Ports in Perspective: Some Comparative Materials on Roman Merchant Ships and Ports. Am. J. Arch. 1988, 92, 553-564. [CrossRef]

54. Leidwanger, J. Maritime Networks and Economic Regionalism in the Roman Eastern Mediterranean. Nouv. l'archéol. 2014, 135, 32-38. [CrossRef]

55. The Oxford Roman Economy Project Shipwrecks Database Version 1.0; Strauss, J. Ed. Available online: Oxrep.classics.ox.ac.uk/databases/shipwrecks_database/ (accessed on 2 December 2018).

56. Leidwanger, J. Between Local and Long-Distance: A Rome Shipwreck off Fig Tree Bay of SE Cyprus. J. Roman Arch. 2013, 26, 191-208. [CrossRef]

57. Karageorghis, V. Cyprus, from the Stone Age to the Romans; Ancient Peoples and Places 101; Thames and Hudson: London, UK, 1982; ISBN 9780500021026.

58. Rautman, M.L. (Ed.) A Cypriot Village of Late Antiquity: Kalavasos-Kopetra in the Vasilikos Valley; JRA Suppl. Ser. 52; Journal of Roman Archaeology: Portsmouth, RI, USA, 2003; ISBN 9781887829526.

59. Hussein, E. Power and Identity in Roman Cyprus. Ph.D. Discussion, University of Warwick, Warwick, UK, 2014; p. 20. 
60. Fujii, T. Imperial Cult and Imperial Representation in Roman Cyprus. Heidelberger althistorische Beiträge und epigraphische Studien 53; Franz Steiner Verlag: Stuttgart, Germany, 2014; ISBN 9783515102575.

61. Parks, D.A. The Roman Coinage of Cyprus; Cyprus Numismatic Society: Nicosia, Cyprus, 2004; ISBN 9789963907007.

62. Karageorghis, V. Sculptures from Salamis I; Salamis 1; Department of Antiquities: Nicosia, Cyprus, 1964.

63. Fejfer, J. Marble Mania: Code-Switching in Roman Cyprus? J. Hell Rom. Mater. C 2013, 2, 169-197. [CrossRef]

64. Davis, T. Saint Paul on Cyprus: Archaeology and the Transformation of an Apostle. Perspect. Sci. Christ. Faith 2012, 64, 230-242.

65. Młynarczyk, J. Nea Paphos in the Hellenistic Period; Nea Paphos 3; Editions Géologiques: Warsaw, Poland, 1990; ISBN 9788301083892.

66. Iacovou, M. Paphos before Palaepaphos: New approaches to the history of the Paphian kingdom. In Epigraphy, Numismatics, Prosopography and History of Ancient Cyprus: Papers in Honour of Ino Nicolaou; Studies in Mediterranean Archaeology and Literature PB 179; Åströms Förlag: Uppsala, Sweden, 2013; pp. 275-291, ISBN 9789170812521.

67. Hohlfelder, R. Ancient Paphos beneath the Sea: A Survey of the Submerged Structures. In International Symposium Cyprus and the Sea; Karageorghis, V., Michaelides, D., Eds.; University of Cyprus: Nicosia, Cyprus, 1995; pp. 191-208, ISBN 9789963607082.

68. Misżk, L.; Papuci-Władyka, E. Nea Paphos and its harbours. Gates to the Mediterranean in the light of the Jagiellonian University research. In North Meets East 3-Aktuelle Forschungen zu antiken Häfen. Ein Workshop veranstaltet von Julia Daum und Martina Seifert an der Universität Hamburg vom 15. bis 17. März 2016; Seifert, M., Ziemer, L., Eds.; Gateways. Hamburger Beiträge zur Archäologie und Kulturgeschichte des antiken Mittelmeerraumes; Shaker Verlag: Aachen, Germany, 2016; pp. 1-19, ISBN 9783844049411.

69. Blackman, D. Sea Transport, Part 2: Harbors. In Oxford Handbook of Engineering and Technology in the Classical World; Oleson, J.P., Ed.; Oxford University Press: Oxford, UK, 2009; pp. 638-671, ISBN 9780199734856.

70. Kaldeli, A. Early Roman Amphorae from Cyprus as Evidence of Trade and Exchange in the Mediterranean. In Transport Amphorae and Trade of Cyprus; Lawall, M.L., Lund, J., Eds.; Gösta Enbom Monographs 3; Aarhus University Press: Aarhus, Denmark, 2013; pp. 123-132, ISBN 9788771242133.

71. Lund, J. A Study of the Circulation of Ceramics in Cyprus from the 3rd Century BC to the 3rd Century AD. Gösta Enbom Monographs 5; Aarhus University Press: Aarhus, Denmark, 2015.

72. Caraher, W. Historical Conclusions. In Pyla-Koutsopetria I: Archaeological Survey of an Ancient Coastal Town; Caraher, W., Moore, R.S., Pettegrew, D.K., Eds.; American Schools of Oriental Research Archaeological Reports 21; The American Schools of Oriental Research: Boston, MA, USA, 2014; pp. 269-299, ISBN 9780897570695.

73. Bekker-Nielsen, T. Transport in Ancient Cyprus. In Transport Amphorae and Trade of Cyprus; Lawall, M.L., Lund, J., Eds.; Gösta Enbom Monographs 3; Aarhus University Press: Aarhus, Denmark, 2013; pp. 12-19, ISBN 9788771242133.

74. Green, J.R.; Stennett, G.H. The Architecture of the Ancient Theatre in Nea Paphos. Rep. Dep. Antiq. Cyprus 2002, 155-188.

75. Michaelides, D. Cypriot Mosaics; Department of Antiquities: Nicosia, Cyprus, 1992.

76. Kondoleon, C. Domestic and Divine: Roman Mosaics in the House of Dionysos; Cornell University Press: Ithaca, NY, USA, 1995.

77. Daszewski, W. Aphrodite Hoplismene from Nea Paphos. Rep. Dep. Antiq. Cyprus 1982, 195-201.

78. Rickman, G.E. The Grain Trade under the Roman Empire. In Seaborne Commerce of Ancient Rome: Studies in Archaeology and History; D'Arms, J.H., Kopff, E.C., Eds.; Memoirs of the American Academy in Rome 36; University of Michigan Press: Ann Arbor, MI, USA, 1980; pp. 261-275.

79. Lund, J. Ceramic fine wares from the 4th century BC to the 7th century AD. In Panayia Ematousa: A Rural Site in South-Eastern Cyprus I; Sørensen, L.W., Winther Jacobsen, K., Eds.; Monographs of the Danish Institute at Athens Volume 6.1; Danish Institute at Athens: Athens, Greece, 2006; pp. 182-230, ISBN 9788772888361.

80. Gordon, J.M.; Cova, E. Romanesis in Cyprus: A Lamp from Athienou-Malloura. Cah. Centre d'Études Chypr. 2010, 40, 277-294.

81. James, S.; Score, V. Akrotiri-Dreamer's Bay (Nissarouin) Excavation and Survey Spring 2018 Interim Report. University of Leicester. Available online: https:/ / www2.le.ac.uk/departments/archaeology/research/ projects/ancientakrotiri/images/DreamersBay2018MarAprinterim.pdf (accessed on 2 December 2018). 
82. Leonard, J.; Demesticha, S. Fundamental Links in the Economic Chain: Local Ports and International Trade in Roman and Early Christian Cyprus. In Transport Amphorae and Trade in the Eastern Mediterranean: Acts of the International Colloquium at the Danish Institute at Athens, September 26-29, 2002; Eiring, J., Lund, J., Eds.; Monographs of the Danish Institute at Athens 5; Aarhus University Press: Aarhus, Denmark, 2004; pp. 189-202, ISBN 9788779341180.

83. Morford, M.P.O.; Lenardon, R.J. Classical Mythology, 6th ed.; Longman: New York, NY, USA, 1999; ISBN 0801319536.

84. Powell, B. Classical Myth, 2nd ed.; Prentice Hall: Upper Saddle River, NJ, USA, 1998; ISBN 0137167148.

(C) 2018 by the author. Licensee MDPI, Basel, Switzerland. This article is an open access article distributed under the terms and conditions of the Creative Commons Attribution (CC BY) license (http:/ / creativecommons.org/licenses/by/4.0/). 